\title{
Harputlu Şâir Rahmî Efendi’nin Neșredilen Divânında Bulunmayan Bazı Şiirleri
}

\section{Some Poems of Rahmi Efendi from Harput which are Not Included in His Released Divan}

\author{
Ahmet KARATAȘ ${ }^{1}$ [1]
}

${ }^{1}$ Sorumlu yazar/Corresponding author: Ahmet KARATAS (Doç. Dr.),

Marmara Üniversitesi, Illâhiyat Fakültesi,

Türk-İslâm Edebiyatı Anabilim Dalı,

İstanbul, Türkiye

E-posta: karatasahmed@gmail.com

ORCID: 0000-0001-8469-2996

Başvuru/Submitted: 17.05 .2020

Revizyon Talebi/Revision Requested: 27.05.2020

Son Revizyon/Last Revision Received:

01.06.2020

Kabul/Accepted: 01.06 .2020

Atıf/Citation: Karatas, Ahmet. "Harputlu Şâir Rahmî Efendi'nin Neşredilen Divânında Bulunmayan Bazı Şiirleri". Şarkiyat Mecmuası Journal of Oriental Studies 36 (2020), 1-42. https://doi.org/10.26650/jos.2020.001

\section{ÖZ}

Hoca Rahmî Efendi, Harput'un (Elazığ) XIX. asırdaki en önemli şâirlerinden biridir. 1217/1802'de Harput'un merkez köylerinden olan Hoğu'da (Yurtbaşı) doğmuş, 1303/1886'da yine orada vefât etmiştir. Harput, Antep ve Kayseri'deki medrese tahsilinden sonra köyüne dönerek orada müderrislik yapmış, vefâtına kadar da ilim ve şiirle meşgul olmuştur. Kendisinden geriye divânı ile Şirâzî'nin Bostan'ına yaptığı Türkçe şerh kalmıştır. Vefâtına yakın divânını düzenleyerek basmaları için dostlarına teslim etmiş, eserin basımıyla kendisinin vefâtı aynı günlere denk gelmiştir. Bu divân birkaç şiir ilâvesiyle iki ayrı neşir olarak bugünkü harflerle de okuyucuyla buluşmuştur. Ankara Üniversitesi Ilâhiyat Fakültesi Kütüphanesi'nde bulunan Harputlu Efendigil âilesine âit kitap koleksiyonuyla ilgili çalışırken Rahmî Efendi'nin en yakın arkadaşı Harput müftülerinden Ömer Naîmî Efendi'nin torunu müftü-müderris Mehmed Kemâleddin Efendi'nin istinsâh ettiği Rahmî Efendi divânını tespit ettik ve bu nüshada onun şimdiye kadar neşredilmemiş bazı şiirlerinin bulunduğunu gördük. Söz konusu koleksiyondaki bir mecmuada onun yayımlanmamış üç şiirine, Ma'mûretülazîz Gazetesi'ni tararken yine divân dışında kalmış üç şiirine daha rastladık. Bunları da yazma divânındaki yayımlanmamış şiirlerine ilâve ederek bu makale vâsıtasıyla neşre hazır hâle getirdik.

Anahtar kelimeler: Harput, Rahmî Efendi, divân, Ma'mûretülazîz Gazetesi

\section{ABSTRACT}

Hodja Rahmî Efendi is one of the most important poems of Harput (Elazığ) in the 19th century. He was born in 1217/1802 in Hoğu (Yurtbaşı), one of the central villages of Harput, and died there in 1303/1886. After his madrasa education in Harput, Antep and Kayseri, he returned to his village and worked there as a mudarris, and he was busy with science and poetry until his death. There are two works of Rahmî: Divan and Şerh-i Bostan. When he was about to die, he edited his Divan and handed it over to his friends for publication. The death of Rahmî Efendi coincided with the printing of the Divan. This work was published separately as two separate publications with the addition of several poems. While I was working on the collection of books belonging to the Harputlu Efendigil family in the Library of Ankara University Faculty of Theology, I found a copy of Rahmi Efendi's manuscript 
divan. In this manuscript I have seen some of his poems that have not been published so far. I added some of the his poems that I came across when I was scanning the newspaper Mamuretülaziz and made them ready for publication with this article.

Keywords: Harput, Rahmi Efendi, divan, Mamuretülaziz newspaper

\section{EXTENDED ABSTRACT}

Hodja Rahmi Efendi is the son of Hodja Ahmed Efendi, a Harput mudarris (scholar). He took lessons from Ahmed Efendi, one of the mufti of Harput, and because of his old age and busyness, he could not spend time and went to Antep with his friends in the madrasah. Along with him, Ömer Naimi, the son of mufti Ahmed Efendi, and Mehmed Emin Lutfi Efendi, the son of mufti Yunus Efendi, also went to Antep. These three friends studied there for a while, but when their teachers were killed during the Janissary revolt, they had to go to Kayseri. They completed their education there and received a icazatnama and returned to Harput in 1242/1826. Rahmi Efendi's friend Ömer Naimi Efendi first became a mudarris in his father's madrasa, and was later appointed as a mufti of Harput. Mehmed Emin Lutfi Efendi also became a mudarris. As for Rahmi Efendi, he became a teacher in the village (Hogu) where he was born and also spent his time writing poems. Although the sources say that he died in 1301/1883-1884, we found that he died in Şaban 1303/May 1886 as a result of our research. There are two works of Rahmî Efendi. One is Divân, the other is Tuhfe-i Dostân Şerh-i Bostân, which is the şarh of Sa'dî-i Şirâzî’s work.

Rahmî Efendi, who knew Persian and Arabic fluently, was one of the most important poems of Harput in the 19th century, besides his scientific personality. The philosophical style in his ghazels resembles Nâbî, the romance style Fuzuli, and the enthusiastic style Nedîm. Nevertheless, he was not insensitive to social issues, as pointed out in this article, he wrote poems depicting the wars made during his time. He also wrote poems for the roads, bridges and fountains built by the governors of the region, and he praised them. According to the information we have reached, he got along well with the governors, wrote praise poems for them and received various awards in return.

In this article, there are some poems of Rahmi Efendi that have not been published so far. In addition to that, we also included three of his poems published in Mamuretülaziz newspaper but not in his Divan. The unpublished poems of Rahmî Efendi are found in a manuscript in the Efendigil Book Collection in the Library of Ankara University Faculty of Theology and in another notebook in this collection. Rahmî Efendi wrote one of these poems for the Mamuretulaziz governor Hasan Hakkı Pasha. Composed of 42 couplets, this poem is praise of Hasan Hakkı Pasha. Another poem of Rahmî Efendi deals with the Ottoman army's capture of Deligrad as a result of the Battle of Aleksinaç between the Ottoman and Serbs in 1876. The 1877-1878 Ottoman-Russian War, which became famous as the "Ninety-Three War", was the 
subject of another poem of Rahmî Efendi. In his poem entitled "Jihâdiyye", Rahmî Efendi praises Sultan Abdulhamid II and the prominent of the Ottoman commanders who led this war. There are also prayers for the victory of the Ottoman Army in Jihâdiyye.

Ömer Naimî Efendi's grandson Kemaleddin Efendi copied the manuscript Divan of Rahmi Efendi, one of the main sources of our article, when he was just 14 years old. Kemâleddin Efendi later became the mudarris of Yusuf Kamil Pasha Madrasa in Harput and the mufti of Mamuretulaziz. He also wrote detailed information about Rahmî Efendi to the famous writer İbnülemin Mahmud Kemal, who also lived in Istanbul. He also sent him a copy from the printed Divan of Rahmî Efendi. While Ibnülemin gave information about Rahmî Efendi in his work Son Asır Türk Şairleri, he benefited from the information that Kemaleddin Efendi sent to him. As a result, the poems of Rahmi Efendi, which we published through this article, are important in that they contain information about the Ottoman-Serbian and Ottoman-Russian wars, especially the Harput cultural history. 


\section{Giriş}

Harput'un XIX. asırdaki meşhur şâirlerinden Hoca Mehmed Rahmî Efendi’nin (ö. 1303/1886) divânı vefât ettiği günlerde Ma‘mûretülazîz Vilâyet Matbaası'nda basılmıştır. Bu divân onun bazı defterlerde bulunan şiirlerinin de ilâvesiyle Gönül Hatay Eren- Halil Erdoğan Cengiz ${ }^{1}$ ve İbrahim Kavaz- M. Naci Onur ${ }^{2}$ tarafından da bugünkü harflerle neşredilmiştir. Harputlu Efendigil âilesiyle ilgili bir müddettir yürüttüğümüz çalışmalar çerçevesinde bu âilenin Ankara Üniversitesi İlâhiyat Fakültesi (AÜİF) Kütüphanesi’ne bağışladığı kitap koleksiyonu arasında Rahmî Efendi divânının bir yazma nüshasına rastlamış ve bunu yakın zamanda yayımladığımız bir makalede duyurmuştuk. ${ }^{3}$ Efendigil âilesinin Osmanlı devrindeki son temsilcilerinden Ma'mûretülazîz müftüsü müderris Mehmed Kemâleddin Efendi’nin (ö. 1936) istinsâh ettiği divân mezkur kütüphanenin Yazma Eserler Bölümü’nde 36812 demirbaş numarasıyla kayıtlıdır. Kemâleddin Efendi 63 varaklık bu nüshayı Ramazan 1298/Ağustos 1881'de istinsâh etmiştir. ${ }^{4}$ Onun 1283/1867'de doğduğu göz önünde bulundurulduğunda ${ }^{5}$ nüshayı 14 yaşındayken istinsâh ettiği ortaya çıkar. Bu erken yaş birçok istinsâh hatâsına da yol açmış görünmektedir. Nüshanın derkenârlarında ayrıca Fıtnat, Rif‘at, Şefîk, Veysî, Hamdî, Hâmî, Hayrî, Nâbî, Bâkî gibi bazı şâirlerin gazelleri yer almaktadır. Bu nüshanın en önemli özelliği Rahmî Efendi’nin bugüne kadar yayımlanan şiirleri yanında gün yüzüne çıkmamış bazı şiirlerini de ihtivâ etmiş olmasıdır. Söz konusu şiirlerden Harput Sâre Hatun (Sarahatun) Camii'nin yeniden inşâsı için yazılan tarih manzûmesi dışındakiler, ${ }^{6}$ AÜİF Kütüphanesi Efendigil Koleksiyonu'ndaki bir mecmuada bulunan üç şiir ve Ma 'mûretülazîz Gazetesi'nde yayımlanan ancak divânında yer almayan yine üç şiir bu makalenin ana konusunu oluşturmaktadır.

Kemâleddin Efendi müretteb divânı istinsâh ettikten sonra (2 $\left.{ }^{\mathrm{b}}-49^{\mathrm{a}}\right)$ Rahmî Efendi'nin hâriçte kalan şiirlerini de deftere kaydetmiştir. Bu şiirlerden 1'i kaside, 4'ü tahmîs, 10'u gazel,

Rahmi-i Harputî Divanı, Ankara: Kültür Bakanlığı Yayınları, 1996.

2 Harputlu Rahmî Dîvânı, Ankara: İzzet Paşa Vakfı Yayınları (Ertem Matbaası), 1996.

3 bk. Ahmet Karataş, "Yeni Bilgiler Işı̆̆ında Harputlu Şâir Rahmî Efendi ve Sâre Hatun (Sarahatun) Camii'nin Yeniden İnşâsına Yazdığı Kaside”, Fırat Üniversitesi Harput Araştırmaları Dergisi, VII/13 (2020), s. 70.

4 vr. $60^{\mathrm{b}}$.

5 bk. Ahmet Karataş, "Harput Ulemâsından Müderris-Müftü Mehmed Kemâleddin Efendi”, Marmara Üniversitesi Ilâhiyat Fakültesi Dergisi, sy. 49 (2015), s. 30.

6 Sâre Hatun Camii'yle alâkalı manzûmeyi müstakil bir makale olarak neşretmiştik. bk. Ahmet Karataş, "Yeni Bilgiler Işı̆ğında Harputlu Şâir Rahmî Efendi ve Sâre Hatun (Sarahatun) Camii’nin Yeniden İnşâsına Yazdığı Kaside", s. 70-77. 
4'ü tarih, 1'i terkîb-i bend, 1'i de tercî-i benddir. Tahmislerin ikisi ile ${ }^{7}$ gazellerin beşi ${ }^{8}$ daha önceki neşirlerde yer almaktadır.

\section{1) Rahmî Efendi'nin Şiirlerinin Muhtevâsı}

\section{a) Yazma Divân Nüshasında Bulunan Yayımlanmamış Şiirleri}

AÜİF Kütüphanesi'ndeki yazma divân nüshasının $49^{\mathrm{b}}-50^{\mathrm{b}}$ varakları arasında Rahmî Efendi'nin 1293/1876'da Ma 'mûretülazîz mutasarrıflığı yapmış olan İşkodralı Hasan Hakk1 Paşa ${ }^{9}$ için yazdığı 42 beyitlik kasidesi bulunmaktadır. Rahmî Efendi kasideyi Hasan Paşa'nın Ma‘mûretülazîz' deki görevine başlaması münâsebetiyle yazıp kendisine takdim etmiştir.

Rahmî Efendi kasidenin nesîb kısmında bir gece vakti mumla yaptığı sohbetten bahsetmektedir. Muma yalnızlığını ve kara bahtını uzun uzun anlatırken gaybten ansızın işittiği bir sesin kendisini teselli edip Hasan Hakkı Paşa'nın gelişini müjdelediğini belirttiği beyitlerle girizgâh kısmını oluşturmakta, sonra medhiyye kısmına geçerek paşanın asîl, âlim, cömert bir kişi olduğunu kaside formunun özellikleri çerçevesinde zikretmekte ve ahâlinin onun gelişine çok sevinerek birbirlerini tebrik ettiklerini yazmaktadır. Kaside sekiz beyitlik tegazzül ve duâ kısmıla tamamlanmaktadır.

7 Bunlardan biri Rahmî Efendi’nin Feyzullah Râif Efendi'nin “Pertev-i hüsnü o şûhun meh-i tâbâna değer/Meh-i tâbâna değil mihr-i dirahşâna değer" matlalı gazeline yaptı̆̆ı "Berk urur lem 'a-i nûr âteş-i sûzâna değer" mısrâıla başlayan tahmistir (vr. 51 b), (neşir için bk. Dîvân-ı Rahmî̀-i Harputî, Ma“mûretü'l-azîz: Vilâyet Matbaası, 1303, s. 105; Cengiz-Eren, Rahmi-i Harputî Divanı, s. 238-239; Kavaz-Onur, Harputlu Rahmî Dîvânı, s. 314-316). Diğeri Ma'mûretülazîz vâlisi Abdünnâfi Efendi’nin "Remîde oldu tabâyı 'vefâdan el çekdi/ Bu ihtilâc ile ol âşinâdan el çekdi”" matlalı gazeline yazdı̆̆ "Vefâ zamânede bay u gedâdan el çekdi" misrâıla başlayan tahmistir (vr. 52a, derkenâr), (neşir için bk. Dîvân-ı Rahmî-i Harputî, s. 104; Cengiz-Eren, Rahmi-i Harputî Divanı, s. 235-236; Kavaz-Onur, Harputlu Rahmî Dîvânı, s. 310-313).

8 Söz konusu gazellerin matla beyitleri şunlardır: "Gâh müjgânı gehî biz ebruvânı söyleriz/ Tîğ-i Behrâm ile tîr-i Kahramânı söyleriz" (vr. 52 '; Cengiz-Eren, Rahmi-i Harputî Divanı, s. 258; Kavaz-Onur, Harputlu Rahmî Dîvânı, s. 350); "Gamze-i nâzik-mizâcın renk alır peymâneden/ Çeşm-i sermestin gelir sandım yine meyhâneden" (vr. 52 ; Cengiz-Eren, Rahmi-i Harputî Divanı, s. 255; Kavaz-Onur, Harputlu Rahmî Dîvânı, s. 350); "Bezm içre her ki ol dürr-i nâ-yâbı söyledir/ Zevk-i şarâb-ı la 'l ile ahbâbı söyledir" (vr. 52 b-53a; bazı kelime farkl1lıklarıyla Cengiz-Eren, Rahmi-i Harputî Divanı, s. 259; Kavaz-Onur, Harputlu Rahmî Dîvânı, s. 346); "Misâl-ı gamze atar çekse ebruvâna beni/ Firâk-ı hicre salar korsalar kemâna beni”" (vr. 53-54a; bazı kelime farkl1lıklarıyla Cengiz-Eren, Rahmi-i Harputî Divanı, s. 241; Kavaz-Onur, Harputlu Rahmî Dîvânı, s. 354); "Nazîre be-Gazel-i Seyfî Defterdâr: Gerçi gamze sihr ile mahmûr şeklin gösterir/ Nergis-i çeşmi velî rencûr şeklin gösterir" (vr. 54a; Cengiz-Eren, Rahmi-i Harputî Divanı, s. 253; Kavaz-Onur, Harputlu Rahmî Dîvânı, s. 348).

9 Hasan Hakkı Paşa 1242/1826'da bugün Arnavutluk sınırları içerisinde bulunan İşkodra'da doğmuştur. Babası Vezir Mustafa Şerifî Paşa'dır (ö. 1276/1860). Çeşitli memuriyetleri arasında 1292/1875-1876'daki Ma‘mûretülazîz mutasarrıflı̆̆ı, 1293/1877'de vezir rütbesiyle atandığı Van valiliği sayılabilir. Halep valisi iken yetersizliği bahane gösterilerek azledilmiş, 1313/1896'da İstanbul'da vefât etmiştir. Hasan Paşa XIX. asrın Mevlevî şâirlerindendir. İbnülemin onun mürettep bir dîvânının varlığından söz etmektedir. (Daha teferruatlı bilgiler için bk. İbnülemin, Son Asır Türk Şairleri, İstanbul: Milli Eğitim Basımevi, 1969, I, 498-500; diğer kaynaklar için bk. Mehmet Arslan, "Hasan Hakkı Paşa, İşkodralı”, http://www.turkedebiyatiisimlersozlugu.com [erişim tarihi: 20.02.2020].) 
$51^{\text {a' }}$ da Harputlu Hayrî Bey'in (ö. 1328/1910) ${ }^{10}$

Dil vermege bir yâr-ı vefâ-perver olaydı

Mestâne-reviş dilber-i nâzik-ter olaydı

matla 'lı gazelinin tahmîsi bulunmaktadır. Hayrî Bey'in şiirlerinin bir kısmını topladığı Hâtıra-i Ahd-i Şebâb’ta (İstanbul: Matbaa-i Osmâniyye, 1302) bu gazel yoktur.

$52^{\text {a' }}$ da Rahmî Efendi'nin Sidkî isimli veya mahlaslı bir şâirin ${ }^{11}$

Kaddün ey serv-i sehî gitdikçe bâlâlanmada

Cilve vü nâz-ı hırâmınla ra 'nâlanmada

matla'lı gazeline yazdı̆̆

$52^{\mathrm{b}}-53^{\mathrm{a}}$ varakları arasında Perâkende Ba 'zı Gazeller başlığıyla divâna sonradan eklenmiş dokuz gazel mevcuttur. Bunların beşi neşredilmiş olduğundan geriye kalan dördünü çalışmamıza dâhil ettik.

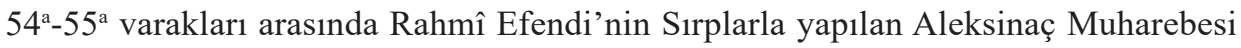
neticesinde Osmanlı ordusunun 1 Eylül 1876'da bugün Sırbistan sınırları içerisinde küçük bir yerleşim yeri olan Deligrad'ı ele geçirmesi münâsebetiyle yazdığ 122 beyitlik tarih manzûmesi bulunmaktadır. Târîh Berây-ı Deligrad başlığını taşıyan bu manzûmede muharebe sahası tasvir edilmekte, ordunun savaştaki kahramanlığı henüz yeni tahta çıkmış (31 Ağustos 1876) II. Abdülhamid'in kudretine bağlanmakta, devrin sadrazamı Mütercim Mehmed Rüşdü Paşa (ö. 1299/1882) abartılı ifadelerle övülmektedir.

$56^{\mathrm{a}}$ 'da Ma'mûretülazîz-Diyarbekir yolunun Maden'deki Mihrap Dağı güzergâhının yapılması münâsebetiyle yazılan tarih manzûmesi vardır. 13 beyitlik bu manzûme esasen devrin Diyarbekir valisi İsmâil Hakkı Paşa medhiyyesidir. ${ }^{12}$ Rahmî Efendi bu manzûmesinde Mihrap Dağı'nın ulaşıma elverişsiz yollarının vali bey sâyesinde düzeltilerek yolcuların perişanlıktan kurtarıldığını belirtmektedir. Sultan Abdülaziz övgüsünün de yer aldığı manzûme duâ ve tarih beytiyle bitmektedir.

$56^{\text {b' }}$ de Harput eşrâfından İshak Efendi'nin 1283/1866' da yaptırdığı çeşme için yazılmış 7 beyitlik bir tarih manzûmesi vardır.

$56^{\mathrm{b}}-57^{\mathrm{b}}$ arasında 5 bend, 35 beyitten oluşan bir tekîb-i bend bulunmaktadır. Rahmî Efendi hikemî tarz ve rindâne bir tavırla kaleme aldığı bu şiirinde dünyevî nimetlere karşı müstağnî

10 Hayatı hakkında bilgi için bk. İbnülemin, Son Asır Türk Şairleri, I, 625-627; İshak Sunguroğlu, Harput Yollarında, İstanbul: Elazığ Kültür ve Tanıtma Vakfı Yayınları, 1959, II, 182-204.

11 Birçok Sıdkî isimli yahut mahlaslı şâir arasında Rahmî Efendi’nin çağdaşı olarak Diyarbekirli kaymakam Mustafa Sıdkî Efendi (ö. 1294/1878) vardır. Bu zât fikir adamı Ziya Gökalp'in dedesidir. Rahmî Efendi’nin şiirini tanzîr ettiği kişi bu Sıdkî Efendi olabilir. (Daha teferruatlı bilgi için bk. Şevket Beysanoğlu, Diyarbakırlı Fikir ve Sanat Adamları, İstanbul: Iş11 Matbaası, 1960, II, 36-38.)

12 İsmail Hakkı Paşa yol, köprü, su kanalları, çeşme yaptırmak, gazete çıkartmak, salnâme hazırlatmak, aşiretleri iskân ve ıslâh etmek, mektepler açtırmak gibi icraatlarıyla adından söz ettiren valilerdendir. 1233/1818'de Kars'ta doğmuş, 1868-1875 tarihleri arasında Diyarbekir valiliği yapmış, 1876'da Erzurum valiliğine getirilmiş, Doksanüç Harbi'ne katılmış, 1314/1897'de İstanbul'da vefât etmiştir. (Teferruatlı bilgi için bk. Oktay Karaman, “Diyarbakır Valisi Hatunoğlu Kurt İsmail Hakkı Paşa'nın Diyarbakır'daki Aşiretleri Islah ve İskân Çalışması [1868-1875]", History Studies International Journal of History: Uluslararası Tarih Araştırmaları Dergisi [Prof. Dr. Enver Konukçu Armağanı], Samsun 2012, s. 227-231.) 
davranılması, fâni şeylere değer verilmemesi, güzel amel ve faydalı ilim peşinde koşulması gerektiğini kaydetmektedir. Ona göre felek kemâl ehline, ârif ve zarîflere rağbet etmez, bu sebeple refâh ve zenginlik peşinde koşmamak lâzımdır. Zira dünyada "bir köhne abâ"yla yetinene Allah kıyâmette cennet elbisesi giydirecektir. Kişi âmirlerin, devlet adamlarının tuzaklarına düşmemeli, onlara meyletmemelidir. Allah insanın her hâline muttalidir; veren O, alan O'dur, yegâne takdir kuvvetine sâhip olan da O'dur. Kişiye yakışan O'nun kaderine teslim olmak, kuldan gelen her şeyi O'ndan bilmektir. Okuyucusunu “İlim irfân incisine tâlip ol! Biriktirdiğin altın, gümüş sana fayda vermez. Sen nasıl baba mirasıyla mutlu olduysan gün gelecek başka vârisler de senin mirasınla mutlu olacak, ömrün boyunca biriktirdiklerini hırsla yağmalayacaklar.” anlamına gelen

Sen dürr-i kerîmâne-i irfânı taleb kıl

Yok fâide cem ' eylediğin sîm ile zerden

Bir gün de ider vâris-i dîgerleri mesrûr

Her nesne ki kaldı sana mîrâs pederden

$* * *$

Cem ' eylediklerin genc-i firâvânı ömrde

Vârisler ider bir gün anı hırs-ile yă̆mâ

şeklindeki beyitlerle uyaran Rahmî Efendi ömrü gafletle geçirmemek gerektiğini vurgulayarak sabahlara kadar tevbe ve duaya devamı tavsiye etmektedir.

Yokdan seni var eyledi ol Hazret-i Mevlâ

Her rûz ma 'âşın sebebin itdi müheyyâ

Bildirmiş iken rızkını taksîm ezelde

İtmek ne revâ sen gibi mahlûka temennâ

beyitleriyle Allah'ın kişiyi yoktan yarattığını ve rızkını ezelden taksim edip belirlediğini ifâde etmekte, hâl böyleyken Allah'a şükretmek yerine kula minnet duymanın yanlışlığına dikkat çekmektedir.

\section{İzz ü şeref-i kadri bilen genc ü gınâdan}

Âzâd olamaz keşmekeş-i renc ü anâdan

Girmez eline dürr-i girânmâye-i maksûd

Gavvâs gibi kesmeyen ümmîdi sivâdan

şeklindeki bazı beyitleriyle Ziyâ Paşa'nın (ö. 1297/1880) meşhur Terkîb-i Bend'indeki 
Bir katre içen çeşme-i pür-hûn-ı fenâdan

Başın alamaz bir dahi bârân-ı belâdan

Âsûde olam dersen ĕger gelme cihâna

Meydâna düşen kurtulamaz seng-i kazâdan

gibi beyitleri ${ }^{13}$ hatırlatan Rahmî Efendi bu manzûmesini onun söz konusu şiirine nazîre olarak kaleme almış gibidir. Muhtevânın ve bazı kâfiyelerin yanısıra her iki manzûmenin vezninin de aynı olması bu ihtimâli kuvvetlendirmektedir.

Rahmî Efendi “Türlü süslerle süslenen bu 'dünya' denilen kadın kimi damat edindi de onu murâdına erdirdi bilmem... Gösterişli konaklarda binbir izzet ü ikrâm ile yaşasan da sonunda yerin bir toprak çukur olacak. Öyleyse bu ömür sermâyeni boşa tüketme, bu cevher bir daha ele gelmez.” mânâsındaki aşağıdaki beyitlerle terkîb-i bendini tamamlamaktadır:

Bilmem kimi dâmâd idinüp kâmını virdi

Böyle zer ü zîverle bezendi zen-i dünyâ

Bir hufre-i hâk olsa gerek meskenin âhir

Sad izzet-ile olsa yerin kasr-ı mu'allâ

Sarf eyleme beyhûde bu sermâye-i ömrün

Rahmî ele girmez hele bu gevher-i yektâ

Rahmî Efendi'nin incelediğimiz divân nüshasındaki son şiiri $58^{\mathrm{a}}-61^{\mathrm{b}}$ arasında bulunan cihâdiyyesidir. Tercî-i bend nazım şekliye kaleme alınan bu 9 bend ve 90 beyitten oluşan manzûmede Doksanüç Harbi konu edinilmiştir. Daha evvel Bosna, Hersek ve Bulgaristan'da başlayan isyanlar 1876'da Sırp ve Karadağ bölgesine de sıçrayınca savaş kaçınılmaz olmuş, isyanı bastırmak isteyen Osmanlı, ordusunu oraya yönlendirmiştir. II. Abdülhamid'in tahta çıkmasından bir gün sonra, 1 Eylül 1876'da, Osmanlı ordusu yukarıda bahsedildiği gibi Sırpları bozguna uğratmış, yapılan mütârekeden Osmanlı kazançlı çıkmış gibi görünmüşse de Rusya ve İngiltere başta olmak üzere büyük devletlerin müdâhelesiyle hâdiseler Osmanlı aleyhine gelişmiş ve Osmanlı'yla Ruslar arasında cereyân eden, Rumî takvime göre 1293 (m. 18771878) yılına rastladığı için Doksanüç Harbi diye anılan savaş meydana gelmiştir. Rusların İstanbul sınırına dayanmasına yol açan bu savaşın neticesinde ağır yenilgiye uğrayan Osmanlı Devleti Balkanlar üzerindeki hâkimiyetini büyük ölçüde yitirmiştir. ${ }^{14}$

13 Eser-i Merhûm Ziyâ Paşa: Tercî-i Bend ve Terkîb-i Bend, İstanbul: Ahmed Kâmil ve Şerîki Matbaası, 1928, s. 6.

14 Teferruatlı bilgiler ve kaynaklar için bk. Enver Ziya Karal, Osmanlı Tarihi: Birinci Meşrutiyet ve Istibdat Devirleri (1876-1907), Ankara: Türk Tarih Kurumu, 2007, VIII, 14-41; Hayriye Yalçın, Sirp Çete Hareketleri ve Osmanlı Devleti (1804-1878), yüksek lisans tezi, 2010, Gazi Üniversitesi Sosyal Bilimler Enstitüsü, s. 65-76; Mahir Aydın, "Doksanüç Harbi”, DİA, İstanbul 1994, IX, 498-499; Ali İhsan Gencer, “Ayastefanos Antlaşması", DIA İstanbul 1991, IV, 225. 
Cihâdiyye başlıklı manzûmenin muhtevâsı harple ilgili olsa da

\section{Sâhibkıran-ı asrdur İskender-i zamân \\ Şevketlü Gâzî Hazret-i Abdülhamîd Hân}

şeklindeki vâsıta beytinden anlaşılacağı üzere ana konusu II. Abdülhamid övgüsüdür. Rahmî Efendi Rusya'nın barışı bozarak uyuyan fitneyi uyandırdığını (savaşa sebep olduğunu), bu sebeple savaşın her müslüman için farz hâline geldiğini belirtmektedir. Artık sevgilinin kaşlarına, kan döken gamzesine bakma vakti değildir; herkesin gözü kılıç ve mızrakların üstündedir. Abdülhamid' in kahraman askerleri düşmanın sırtını yere seren pehlivanlar gibidir. İkinci bendde Abdülhamid'i, üçüncü bendde sırasıyla Plevne kahramanı Gazi Osman Paşa (ö. 1317/1900), Şıpka kumandanı Süleyman Hüsnü Paşa (ö. 1310/1892), Erzurum müdâfii Gazi Ahmed Muhtar Paşa (ö. 1337/1919), Batum ordusu kumandanı Derviş İbrahim Paşa (ö. Muharrem 1314/Haziran 1896) ve Erzurum valisi İsmail Hakkı Paşa’yı (ö. Ramazan 1314/ Şubat 1897) medheden Rahmî Efendi manzûmesinde ana hatlarıyla Osmanlı ordusunun kahramanlığını, düşmanların ise zilletini nazmetmekte, manzûmesini II. Abdülhamid ve ordu için yaptığı dualarla tamamlamaktadır.

Divân nüshasının son varağında (62a) Rahmî Efendi'nin Abdülhamid Hamdî Efendi’ye

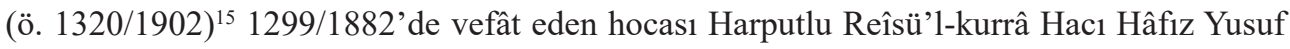
Efendi'nin ${ }^{16}$ vefâtı münâsebetiyle yazdığg taziyenâmesi vardır. Kemâleddin Efendi babasının cevâbını da taziyenâmenin altına yazmaya başlamış ama yarım bırakmıştır.

\section{b) AÜİF Kütüphanesi Efendigil Koleksiyonu'ndaki Bir Mecmuada Bulunan Şiirleri}

AÜIFF Kütüphanesi'ne bağışlanan Efendigil Koleksiyonu'nda bulunan bu mecmua 0036 demirbaş numarasıyla kayıtlıdır. Mecmua Abdülhamid Hamdî Efendi ve Kemâleddin Efendi'nin el yazılarıyla yazılmış olup dinî ilimlere dâir birtakım notlar ihtivâ etmektedir. Bu mecmuadaki üç şiirden ilki Abdülhamid Hamdî Efendi'nin 1274/1857'de dünyaya gelen büyük oğlu Mehmed Said Efendi’nin (ö. 1926) doğumu münâsebetiyle kaleme alınmıştır. Rahmî Efendi bu manzûmesinde Abdülhamid Hamdî Efendi'yi tebrik etmekte, Mehmed Said Efendi'nin de ilim ve fazîlette ismini taşıdığı büyük dedesinin vârisi olmasını dilemektedir.

Söz konusu mecmuada bulunan ikinci şiir Rahmî Efendi'nin yaklaşık yetmiş yıllık arkadaşı, yoldaşı, en yakın dostu Harput müftülerinden Ömer Naîmî Efendi’nin vefâtı (1299/1882) için yazdığı tarih manzûmesidir. Manzûmenin muhtevâsından Rahmî Efendi’nin bunu Ömer Naîmî Efendi'nin mezar taşına hakkedilmek üzere kaleme aldığı anlaşılmaktaysa da mezar taşına Naîmî Efendi’nin oğlu Abdülhamid Hamdî Efendi’nin manzûmesi hakkedilmiştir.

15 Abdülhamid Hamdî Efendi Kemâleddin Efendi’nin babasıdır. Hafız Yusuf Efendi kendisine ilm-i edâ ve kıraat-i seb'a icâzeti vermiştir. (Hayatı hakkında teferruatlı bilgi için bk. İbnülemin, Son Asır Türk Şairleri, I, 548-551; İshak Sunguroğlu, Harput Yollarında, II, 156-163.)

16 Hayatı hakkında teferruatlı bilgi için bk. İshak Sunguroğlu, Harput Yollarında, II, 278-280. 
Mecmuadaki son şiir ise Rahmî Efendi'nin Harputlu zengin Ermenilerden Naum Efendi'nin vefatı sebebiyle yazdı̆̆ı bir kıt'adır.

\section{c) Ma'mûretülazîz Gazetesi’nde Yayımlanan Şiirleri}

Rahmî Efendi'nin Ma 'mûretülazîz Gazetesi'nde zaman zaman bazı şiirleri neşredilmiştir. Bu şiirlerden tespit edebildiğimiz üçü divân neşirlerinde bulunmamaktadır. ${ }^{17}$ Her üç şiir de dönemin Ma'mûretülazîz valisi Hasan Hakkı Paşa'nın yaptırdığı üç farklı çeşme için kaleme alınmıştır. Bunların ilki gazetenin 15 Ramazan 1302/29 Haziran 1885 tarihli, 88 numaralı nüshasında yer almaktadır. Nüshanın ilk sayfasında manzûmeyle birlikte yer verilen bilgi notuna ve Divân-1 Harb memuru kâtip Mustafa Sabrî Bey’in konuyla ilgili mektubuna göre Hasan Hakkı Paşa Arapgir- Dişterik Yazısı- Ma‘mûretülazîz yolu üzerindeki Haraççı Çeşmesi’nin yıkılması sebebiyle aynı yere kârgîr bir çeşme yaptırmış, Rahmî Efendi de çeşme başına hakkedilmek üzere bir tarih yazmıştır. Söz konusu bilgi notu şu şekildedir:

Arapgir ciheti tarîki kemâl-i ehemmiyetle tesviye olunmakda olduğu gibi bu tarîka me'mûr hânedân-ı mahalliyeden Edhem ve Alaybegizâde Mehmed ve Derbederyan Minas Efendilerin hıdemât-ı mebrûre ibrâzına muvaffak olacakları kaviyyen me'mûl ve muntazar olduğuna ve Dîvân-ı Harb-ı Husûsî'ye me'mûr Mustafa Efendi tarafindan matbaamıza mersûl mektup meâli dahi bu merkezde bulunduğuna binâen mektûb-ı mezkûr ile zât-ı âlî-i vilâyetpenâhînin mezkûr tarîki muâyene buyurdukları esnâda inşâsını irâde buyurmuş oldukları çeşmeye dâir memleketimiz şuarâ-yı benâmından fazîletlü Rahmî Efendi tarafindan inşâd edilen târîh ber-vech-i âtî derc olunur.

Mustafa Sabrî Bey'in mektubu ise şöyledir:
Muharrir Efendi,
Arapgir tarîkinden geçerek geçenlerde buraya geldim. Sâye-i ma 'mûriyet-vâye-i cenâb-ı hilâfetpenâhîde eser-i umrân-perver-i âlî-i vilâyetpenâhî cümle-i cemîlesinden olarak mevsim-i sayfde bile bataklığından geçilemeyen Dişterik tarîki pek mükemmel olarak tesviye edilmekde olduğunu gördüm. Himmetü'r-ricâl tekla 'u'l-cibâl ${ }^{18}$ nutk-ı celîli mâsadakınca pek çok sa 'bu'l-mürûr sengistân mahaller şose yapılmış ve hele Haraçcı Çeşmesi deyu ma 'rûf olan bir menba-ı âb-ı zülâl evvelleri istifâde olunmaz bir hâl-i harâbiyyet kesb itmiş iken bu kere mârrin ü âbirînin def-i harâret-i atşânî içün şeref-ta 'alluk iden irâde-i isâbet 'âde-i vilâyetpenâhî üzerine tarîk-i mezkûr me'mûru Arapgir hânedânından Alaybegzâde fütüvvetlü Mehmed Efendi'nin gayret ü ikdâmı semeresiyle kârgîr olarak inşâ itdirilmiş ve nâm-ı âlî-i vilâyetpenâhîye nisbetle hüsn-i hitâmını müs 'ir bir de târîh taşı hakk ü ta 'likk edilmek mukarrer bulunmuşdur. Mûmâileyh Mehmed Efendi ile müteneffizân-ı memlek[et]den tesviye-i tarîk komisyonuna me'mûr zevâtın her hatvede hüsn-i himmet ve ikdâmları eseri meşhûd bâsıra-i ibtihâc olmuş olduğunu ma 'a 't-teşekkür arz eylerim.
Dîvân-ı Harb-i Mahsûs'a me'mûr kâtib Mustafa Sabrî̀

\footnotetext{
17 Ma 'mûretülazîz Gazetesi'nin bütün sayılarının yer aldığı bir koleksiyon maalesef yoktur. Bizim tespitlerimiz gazetenin Milli Kütüphane'deki 1882-1886 yıllarına ait 140 sayılık eksik koleksiyonuna dayanmaktadır.

18 "İnsanların gayret ve yardımı dağları devirir." anlamına gelen bir Arap tabiridir.

19 Ma 'mûretülazîz Gazetesi, nr. 88, 15 Ramazan 1302/29 Haziran 1885, s. 1.
} 
Rahmî Efendi burada bahsedilen şiirinde Ma'mûretülazîz’in imâr ve inşâsı için çalışan valiyi övmekte, yaptırdığı bu çeşmeye karşılık Kevser havuzuyla müjdelenmesini Allah’tan niyâz etmekte ve

Böyle inşâ eyledi Hacı Hasan Beg çeşmeyi

Gel de nûş eyle hemân bânîsine eyle du' $a ̂$

beytiyle çeşmenin tarihini düşmektedir.

Rahmî Efendi'nin ikinci tarih manzûmesi gazetenin 20 Şevvâl 1302/2 Ağustos 1885 tarihli, 92 numaralı nüshasında yer almaktadır. Rahmî Efendi bu şiiri kezâ vali Hasan Hakkı Paşa’nın Elazı ğ- Malatya yolu üzerindeki İzolu civarında bulunan Melîkân Köprüsü’nün bitişiğine yaptırdığı çeşme münâsebetiyle yazmıştır. Gazete manzûmeyi şu haber metniyle yayımlamıştır:

Sâye-i umrân-vâye-i cenâb-ı pâdişâhîde tesviye olunan İzolu ciheti tarîkinin merkez-i vilâyete altı sâat mesâfesinde ve müceddeden inşâ olunan Melîkân Köprüsü ittisâlinde bir mâ-i lezîz zuhûr etmesiyle atûfetlü vâli begefendi hazretlerinin kîse-i mürüvvetlerinden yapdırllan çeşmeye dâir memleketimiz şuarâ-yı benâmından fazîletlü Rahmî Efendi'nin söylediği târîh-i selîsdir. ${ }^{20}$

Rahmî Efendi'nin üçüncü manzûmesi yine valinin Ma'mûretülazîz'in güneydoğusunda, Gölcük (Hazar Gölü)- Maden güzergâhında, merkeze 30-35 km. mesâfedeki KarasazDeveboynu-Maden geçidi üzerinde yaptırdığı çeşme için kaleme alınmıştır. Ma 'mûretülazîz Gazetesi'nin 19 Zilka'de 1302/30 Ağustos 1885 tarih ve 96 numaralı nüshasında bulunan konuya dair haber şöyledir:

Sâye-i umrân-vâye-i cenâb-ı pâdişâhîde tesviye olunan Deveboynu tarîki üzerinde atûfetlü vâli begefendi hazretleri taraf-ı eşreflerinden ma ârif müdîri izzetlü Murâd Efendi nezâretiyle inşâ buyurulan çeşmeye dâir ulemâ-yı benâm ve şuarâ-yı belâgat-ittisâmdan fazîletlü Rahmî Efendi'nin söylediği târîhdir. ${ }^{21}$

20 Ma'mûretülazîz Gazetesi, nr. 92, 20 Şevvâl 1302/2 Ağustos 1885, s. 2-3.

21 Ma'mûretülazîz Gazetesi, nr. 96, 19 Zilka'de 1302/30 Ağustos 1885, s. 2. 
2) Rahmî Efendi'nin Divân Neşirlerinde Bulunmayan Şiirleri

a) AÜİF Kütüphanesi'nde Bulunan Yazma Divânındaki Manzûmeler

[49 $]$ Vâlî-i Vâlâ-şân-ı Van Devletlü Hasan Paşa Hazretleri Pîşgâh-ı Âlîsine Kable’lVizâre Ma'mûre Mutasarrıflı̆̆ı Hengâmında Takdîm Kılınan Kasîdedür

[fe 'ilâtün (fầ 'ilâtün) fe 'ilâtün fe 'ilâtün fe 'ilün]

1. Dün gice şem'-i şebistân-1la oldum hem-dem Kalmadı bezmde çün gâile-i nâ-mahrem

2. Didüm ey encümen-efrûz-1 nedîmân-1 şühûd Tek ü tenhâ ben iken bezmde kaldın sen hem

3. Dilde te'sîr iderek sûz u güdâzın eseri Âteş-i hasret-ile dîdeler oldu pür nem

4. Bâri efsâneleri yâd-1la takrîre getür Gitdi kûy-1 'ademe cümle enîs ü hem-dem

5. Ne gelür yanıma bir mûnis-i gamhâr nedîm Ne sorar hâl-i perîşân-1 dili bir âdem

6. Bâri yok bâde-i gül-reng-i safâ-bahş-1 derûn Nûş idüp kalmaya tâ dilde olan renc-i elem

7. Bâri yok tarf-1 sanem sâkî-i ferhunde-likā Ola gül-bister-i vaslında gönüller hurrem

8. Bâri yok nabz-şinâs ehl-i mürüvvet ki anın Yed-i ihsânı ide rîş-i derûna merhem

9. Oldum üftâde vü pâmâl-1 hümûm-1 gerdûn Dest-gîrim olacak kalmadı bir ehl-i kerem

10. Çekilüp kûşe-i endîş̧eye dil zâr u hazîn Aldı hep gûl-1 beyâbân gibi etrâfımı gam 
11. Didüm ey tâli'-i bed-hâh nedür n'oldı sana Bu da lâyık mı felek ide bana cevr ü sitem

12. Öyle tûtî-i şeker-hâ-yı belâgatken ola Kalemüm kûşe-i endîşede lâl u ebkem

13. Kâh ben baht-1 siyâhımla idüp bahs ü cedel Kâh gerdûna hitâb eyleyüp itdüm mülzem

14. Nâgehân itdi nidâ gûş-1 dile mülhim-i gayb Böyle tenbîh ile cân u dilim itdi hurrem

15. Reh-i şekvâda dedi yorma semend-i emelün Ey cefâkeş ki budur şimdi tarîk-i eslem

16. İzz ü ikbâl ü şeref eylediler istikbâl Geldi çün rütbe-i bâlâ ile mîr-i ekrem [50

17. İtdi Ma'mûre’yi teşrîf hükümrân oldı Birbirin yümn-ile tebşîr ider ehl-i âlem

18. Ona mebrûre-i tebrîk yazup arz eyle İşte hâl-i dili arz itmege levh işte kalem

19. Ya'nî fahrü'l-ümerâ kurre-i ayn-i vüzerâ Gevher-i kân-1 sehâ necl-i vezîr-i a'zam

20. Nâm-1 vâlâsı gibi hulkı hasen mîr-i kerîm Himmeti rütbe-i vâlâsı gibi müstahkem

21. Güher-i kân-ı ma'ârifdür deryâ-yı himem Asrda zâtına hasr oldı anun lutf u kerem

22. Hânedân-zâd ki hep silsile-i tâhiresi İftihâr-1 vüzerâ vü vükelâ-yı efham²2 
23. Kadr-dân-1 ulemâ vü zurefâ-perverdür Vasf ider şânını ihsânını söyler âlem

24. Şimdi ol zât-1 himem-ver-i âlî-nesebin Hükm ider rây-1 sedâdına Felâtun-hikem

25. Biri düşmen-şiken ü biri debîr-i irfân Yed-i çâlâkına râm oldı anun seyf ü kalem

26. Gösterür aczi şümârında benân-1 efkâr Lutf u ihsânı hesâb itseler erbâb-1 alem

27. Sürmedür dîde-i âmâle bugün hâk-i deri Gıbta eylerse revâ kuhl-i Sıfâhân-1 Acem

28. Dâverâ sen de safâlarda olup şâd ol kim Yümn-i teşrîfin ile oldı gönüller hurrem

29. Ben de bu şevk-1la bir turfe gazel tarh ideyim Ezber itsün okusun ehl-i ma'ârif her dem

30. T1fl-1 nev-sâl döküp gerden-i sâfa perçem Şiken-i zülf-i bütân gibi idüp ham-der-ham

31. Çemistân-1 melâhat mi riyâz-1 hüsnü Her 1kd-ı kâkülü şebbû ruhı gül goncesi fem

32. Lü'lü-i ter gibi hûy-kerde gören ruhsârun Zan ider berk-i gül-i tâzeye düşmüş şebnem [50 $[5$

33. Çünki yok vech-i şebeh ayn-1 Hitâ olmaz mı Çeşm-i bîmârına âhû-yı Hoten'dür der isem

34. Zîr-i hatda görünen nokta-i mevhûme demiş Dehenün tengini vasf eyleyen erbâb-1 kalem

35. Leb-i dilber gibi dil-mürdeler itmez ihyâ Câmını boş yere bezminde tolandırmış Cem 
36. Güher-i pendimi gûşunda kılup itme hazer Bûs idersem lebün esrârını ağyâra dimem

37. Rahmiyâ eyleme 1tnâb-1 sühan geldi yeri Câhı tebrîkle bir hayr du'âdır elzem

38. Nitekim yümn ile devr ide sipihr üzre nücûm Nitekim mihre ola mâh-1 Muharrem mahrem

39. Olsun ol zât-1 kerem-pervere yâver tevfîk Kevkebi sa'd ola ikbâli ile bahtı tev'em

40. Müteselsil ola ömrü nice mâh u nice sâl Âfiyetlerle tolansun şeb ü rûzı her dem

41. Kendüsi sûr-1 sürûr-ile ide zevk u safâa ${ }^{23}$ Eylesün düşmen-i bed-hâhı olanlar mâtem

42. İre tâ matlab-1 a'lâlara ber vefk-1 murâd Kasr-1 âmâline her mâh-1 nev olsun süllem

\section{[51ª] Tahmîs-i Gazel-i Hayrî Efendi ${ }^{24}$}

[mef' ûlü mefâ 'îlü mefâ '̂̀lü fe 'ûlün]

1. Bir lebleri mül ruhları gül dilber olaydı Peymâne be-kef sâkî-i simîn-ber olaydı Her gamzesi bu sîneme tek hancer olaydı Dil vermege bir yâr-ı vefâ-perver olaydı Mestâne-reviş dilber-i nâzik-ter olaydı

2. Encâmı ne oldu dil-i dîvâne-i Kays'ın Peymân-şiken oldukları peymâne-i Kays'ın Sormazdı hikâyâtını cânâne-i Kays'ın 
Yâd itmez idi ismini efsâne-i Kays'ın

Âlemde benim hâlimi bir anlar olaydı

3. Gülzâr-1 muhabbetde olup râzıma mahrem

Bu nağme-i dilsûzumu gûş eylese bir dem

İnsâfa ri'âyet k1lup elbet olur epsem

Bî şübhe olur bülbül-i şeydâ hele ebkem

Her şâm u seher nâlelerim dinler olayd

4. Sen Misr-1 melâhatde eyâ Yûsuf-1 Ken'ân

Bu hüsn-ile bir geldin olup âfet-i devrân

Yok mihr-i münevver gibi şimdi sana akrân

Mülk-i dili vermezdim eger ey şeh-i hûbân

Mahrûse-i hüsn içre sana benzer olaydı

5. Yazmış kalem-i kudret gör hüsni beyânda

Âyîne-i ruhsâra nigâh itse nihânda

Bîgâneye yüz vermez idi gördügü anda

Meyl itmez idi zümre-i ağyâra cihânda

Ol serkeş ĕger nushı kabûl eyler olaydı

6. Dilde elem-i firkat başımda bu sevdâ

Hicrinde bu ömrüm güzerân etmede hayfâ

Rahmî yine ben itmedeyim vasl-1 temennâ

Terk eyler idi cevrini Hayrî felek ammâ

Bu tâli'-i nâ-sâz bana yâver olaydı

$* * * * * * * * *$

\section{[52ª Tahmîs-i Gazel-i Sıdkî}

[fâ 'ilâtün fâ 'ilâtün fâ 'ilâtün fâ 'ilün]

1. Ey mehim mir'ât-1 ruhsârın mücellâlanmada

Fahr ider âhûlara çeşmin de şehlâlanmada

Hâsılı hûbâna hüsnün şimdi a'lâlanmada

Kaddün ey serv-i sehî gitdikçe bâlâlanmada

Cilve vü nâz-ı hirâmınla ra 'nâlanmada 
2. Bağrı hûndur bâde yâd itmiş leb-i gülfâmını

Sâgar-1 Cem'den füzûn revnakda dirler câmını

Şimdi âşıklar senün âlemde söyler nâmını

Mihr-i aşkım parladır âyîne endâmını

Nazra-i pâkimle hüsnün revnak-efzâlanmada

3. Kara bahtım yâd idüp hatt-ı siyâhından senin

Sürme itdim dîdeye bu hâk-i râhından senin

Nahvetin bildim gurûr-1 kec-külâhından senin

Nâ-ümîd-i vasl idim hışm-ı nigâhından senin

Gayrı çeşmin vaslını uş̧̧âka îmâlanmada

4. Bezme geldin sevdiğim mestâne hâl oldı yaman

Gamzeler pür nâz ü kâküller perîşân el-amân

Gördüler sâgar be-kef mest oldu âşıklar hemân

Aks-i reng-i bâde mi çeşmin mi hâlet-bahş olan

Ruhların bir neş'e-i dîgerle sahbâlanmada

5. Kîmyâdır nazrası dirlerse sâhib-devletin

Rahmiyâ bîgâne-rû olma revâc-1 kıymetin

Nev-arûs-1 nazmı tezyîn itmek olsun niyyetin

Şâne-i enzâr-l feyz-ile bir ehl-i himmetin

Şâhid-i nazmım dem-â-dem Sıdkî a 'lâlanmada

[52 $\left.{ }^{\mathrm{b}}-53^{\mathrm{a}}\right]$ Perâkende Ba' ${ }^{6} \mathrm{zı}$ Gazeller

[mefâ îlün mefâ îlün mefâ îllün mefâ 'îlün]

1. Reh-i âmâlini ta'mîre düşmüş halka râhat yok

Bilinmez maksad-1 âlem nedir kim istirâhat yok

2. Aceb hayretdeyim ta'bîr-i nâ-bercâ-yı ilkāya

Kalem de bildi kim ma'nâca imlâ-yı sa'âdet yok

3. Nifâk-âlûde çirkâb-1 riyâdır tab'-1 nâ-pâki

Rakîb-i zişt-rûda kim demiş kim bir kabâhat yok 
4. İmâret-sâz olurken şâhrâh-1 kûy-1 âmâli

Yine kûyunda kân-1 kâma bir câ-yı selâmet yok ${ }^{25}$

5. Devâsâz olmadı nabz-âşinâlar derd-i hicrâna

Etıbbâ-yı zamânın rây-1 fikrinde hazâkat yok

6. Çemende serv-ile bir kāmet-i dildârdan gayrir ${ }^{26}$

Hele seyr it cihânda kimsede bir istikāmet yok

7. Gönül vermek revâ mı Rahmiyâ derbend-i devrâna

Devâm üzre güzergâh-1 fenâda çün ikāmet yok ${ }^{27}$

$* * * * * * * * *$

[mef' 'ulü fâ 'ilâtü mefâ 'îlü fâ 'ilün]

1. Hüşyâr olup da la'l-i lebin yâda gelse de

Def'-i humâra neş'e verir bâde gelse de

2. Eyler hücûm leşker-i gam hicr-i yârda

Sâkî piyâle elde bir imdâda gelse de

3. Bîdârlıkda yâr olamaz mutlakâ nasîb

Âgûş-1 vasla bârî o rü’yâda gelse de

4. Bilmez bu zevk-i aşk nedir söylemez cevâb

Şîrîn bu râzı sormağa Ferhâd'a gelse de

5. Yârin hayâl-i hicri komaz dilde bir sürûr

Îd-i visâli hâtır-ı nâ-şâda gelse de

6. Zeyn eylemiş mi la'lini görsem gubâr-1 hat

Mihr-âşinâ-yı şevk olup ol sâde gelse de

25 "kûyunda" kelimesinde "كو" hecesi yazılmamıştır.

26 "dildârdan" kelimesinin son hecesindeki "ə" harfi yazılmamıştır.

27 Rahmî Efendi'nin bu gazeli Nâbî'nin aynı varağın derkenârında bulunan “Derûnumda keder var ye’s ü ümmîde liyâkat yok/Visâle kābiliyyet mihnet-i hicrâna tâkat yok” matla“lı gazeline nazîredir. 
7. Âşûbgâh-1 fitneyi gösterse âleme [53 $]$

Rahmî o tîğ-i gamzeler âmâde gelse de

$* * * * * * * * *$

[mef'vilü mefấ 'îlü mefâ 'îlü fe 'ûlün]

1. Zâhid yine rindâna ider zühd-ile pendi

Ol pendi riyâydı hemân kendi beğendi

2. Sâkî şeker-âb oldı bu şehdâbe-i vaslın

La'lin dahi sun tâ ki mükerrer ola kandi

3. Bilmem kimi dâmâd idinüp kâmını verdi

Böyle zen-i dünyâ zer ü zîverle bezendi

4. Zeyn eyledi bâğ-1 emeli cûy-1 sirişkim

Dil aldı hayâle yine bir serv-i bülendi

5. Gîsûlarını yâd ile sevdâlara düşdü

Dîvâne gönül boynuna takdı dü kemendi

6. Sarf itmedi beyhûde o sermâye-i ömrün

Bâzâr-1 cihân içre bilen sûd u gezendi

7. Akl u dili sabrın gibi yağmâya verirsin

Rahmî hazer it sevme sen ol şâh-1 levendi

$* * * * * * * * *$

[fe 'ilâtün (fâ 'ilün) fe 'ilâtün fe 'ilâtün fe 'ilün]

1. Yâre lutf itmeden âzârlık ağyâre düşer

Güle nermiyyet de tîğ-i sitem-i hâre düşer

2. Gönül üftâdesidir hâl ü hatt-1 cânânın

Rakam-1 bahtımı resm eyleseler kara düşer 
3. Şeb-i endîşede tıfl-1 dil-i nevres düşünür

Târ-1 zülfün acabâ kimlere gehvâre düşer

4. Dîdemizden nem-i hasret kesilür ol gice kim

Tûtiyâ-yı nazarın nergis-i bîmâre düşer

5. Ben o şîrîn-sühana râz-1 derûnum der idim

Korkarım dil yine sevdâ ile dağlara düşer

6. Şiken-i zülfüne pâ-bend-i hayâl olmasa da

Dâm-1 gîsûlara mürg-i dil-i bîçâre düşer

7. Şem-i ruhsâre nigâh itme hazer kıl zinhâr

Rahmiyâ aşk-1la pervâne-i dil nâre düşer

[54] Târîh Berây-ı Deligrad

[mefâ‘îlün (fe‘ilâtün) mefâ‘îlün (fe‘ilâtün) mefâ‘îlün mefâ‘îlün]

1. Şehinşâh-1 zamân Abdülhamîd Hân-1 cihânbânın

Kemâl-i şevketin 1zhâr ider ol Kâdir-i allâm [54b]

2. Cihâd içün miyâna bend idüp şimşîr-i Fârûkî

Adû-yı dîn-i bed-âyîne hergiz virmedi ârâm

3. Hümâ-yı devleti zîr-i cenâhında masûn olmuş

Bihamdillâh hatardan sâlim oldı beyza-i İslâm

4. Sikender-tab'dur kim eylemiş sadr-1 vekâletden Aristo-menkıbet bir âsaf-i zîşânı istihdâm

5. Emîn-i mülk ü millet Bû Ubeyde-meşreb ü sîret Alî haslet Muhammed Rüşdî Paşa dâver-i eyyâm

6. Nizâmülmülk-i devletdir bu kim rây-1 savâbında Nazîrin defter-i ahbâra hergiz yazmadı aklâm ${ }^{28}$

28 Kemâleddin Efendi "nazîrin” kelimesini "nazarîn” okunacak şekilde yazmıştır. 
7. Sürûş-1 gaybdandır vâridât-1 hüsn-i tedbîri

Dil-i dânâsına re’yinde istikbâl ider ilhâm

8. Sevâd-nâmesi i'lân-1 harb itdikde a'dâya

Karatağluları da'vâlarında eyledi ifhâm

9. Cevâba iktidârı eşkiyânın kalmadı zîrâ

Adû-yı devleti seyf-i şerî‘'atle ider ilzâm

10. Dimâğ-1 cünd-i şâhî zevk-i şehd-i âyet-i nusret ${ }^{29}$

Nevâl-i sofra-i ceng ü vegâdan itdi şîrîn-kâm ${ }^{30}$

11. Ser-â-pâ şimdi mansûrü'l-livâdur ceyş-i sultân $\hat{\imath}^{31}$

Deligrad'ı dahi aldı cihâd-ile idüp ikdâm

12. İder pâmâl kûh u deşt-i Surbistan'i hep leşker

Penâh itmekde bir yer kalmadı a'dâ-yı bed-fercâm

13. Cihânı kaplayınca rezm-gâhın dûdı gâzîler

Dem-â-dem bu hevâdan bû-yı nusret eyler istişmâm

14. Zafer-yâb oldılar top u tüfenk ü seyf-i şâhla

Dilîrâne bu meydân-1 vegâda ceng idüp İslâm

15. Değil top ejdehâdur sihrini ibtâle a'dânun

Saçar âteşleri hep tâğiyânı itmege i‘dâm

16. Degil üsrüb ebâbîl-i kazâ siccîl idüp irsâl

Helâk eyler adûyı sû-i kasdın eyleyüp i'lâm

17. Zemîn-i teşneyi kandırmağa ya hûn-1 a dâdan

Şarâb-1 âlgûn işrâb ider bu çerh-i mînâ-fâm

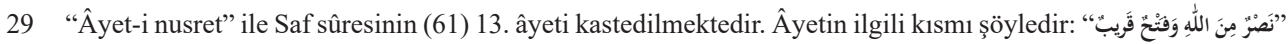
(Allah katından bir yardım ve yakın bir zafer vardır.)

30 Kemâleddin Efendi "ceng ü vegâdan" ibâresini "ceng ü du 'âdan" şeklinde yazmıştır. Ancak bu okuyuş beytin anlam bütünlüğünü bozmaktadır. Kemâleddin Efendi’nin sehven öyle yazdığ kanaatindeyiz.

31 Bu mısrâdaki "mansûrü’l-livâ" ibâresinde "livâ"nın "elif"i yazılmamıştır. 
18. Dem-i sürh-ile ya âşûbgâhla eyleyüp tahrîr Kazâ şimşîr-i rezmi eyler isti'mâli isti'lâm

19. Nice tâb-âver olsun pençe-i şîrân-1 İslâm'a Virür rûbâh-tiynet gerçi dîne yine istihkâm

20. Hımâr-1 vahşdır gûyâ ki düşmen eyler istinfâz Dehân açmış gazanferler gibi şimşîr-i hûn-âşâm [55ª ]

21. Mücevher tîğler-ile ceng olur Rahmî didüm târîh Deligrad'a kılıç kanlaya girdi asker-i İslâm

دليغراده قلج قانليه كيردى عسكر اسلام

1293 [1876]

22. Hurûf-1 gayr-1 menkût-ile Rahmî söyledim târîh Deligrad'ı basıp tur ile girdi asker-i İslâm

دليغرادى باصوب طور ايله كردى عسكر اسلام

1293 [1876]

$* * * * * * * * *$

[56'] Târîh Berây-ı Tesviye-i Tarîk-i Mihrâb Bâ-himmet-i İsmâ‘îl Hakkı Paşa Vâlî-i Vilâyet-i Diyârbekir

[fâ 'ilâtün fâ 'ilâtün fâ 'ilâtün fâ'ilün]

1. Hazret-i Abdülazîz Hân Sikender-câh kim

Zâtı evreng-i şehinşâhîde bî-misl ü adîl

2. Meslek-i kānûn ahdi şâhrâh-1 müstevâ

Sâye-i adli cihân-peymâlara zıll-1 zalîl 
3. İstivâ-yı râh ser-tâ-ser olupdur mültezem Ka‘be-i âmâle şimdi istemez gayrı delîl ${ }^{32}$

4. Kāmet-i Mihrâb'a lâzım oldı gûyâ bir kemer Dâmeninden açdı yol kûh-1 bülend oldı zelîl

5. Atf idüp bu rehrevânın seyrine meyl-i derûn Kûh u sahrâ hep yapılmak üzre yollar meyl-i mîl

6. Hak muvaffak eylemiş bir âsaf-1 zî-şâna kim

Hüsn-i tedbîri anun re'y-i Felâtûn-mesîl

7. Ya'nî İsmâ‘̂̂l Paşa vâlî-i âlî-tebâr

İstikāmetle cihânda buldu ol kadr-i celîl

8. Hasr-1 evkāt eyleyüp tenkîd-i emr-i devlete Hep yolunda sa'y-ile kesb eyledi zikr-i cemîl

9. Sa'b iken râh-1 şevâhık tîşe-i tedbîrle Rehrevâna kûhlara ban virüp virdi sebîl

10. Bu tarîk-ile cihân âsûde oldu seyrde Sâlikânı hem yorulmazlar hem olmazlar sefîl

11. Rûz şeb seyr eyleyenler böyle itsünler du'â Pâdişâh-1 âleme virsün Hudâ ömr-i tavîl

12. İki kit‘a Rahmiyâ târîhle ilhâm-1 gayb Rehrevâna böyle tenbîh eyledi bî-kāl ü kîl ${ }^{33}\left[56^{\mathrm{b}}\right]$

32 Birinci mısrâdaki “mültezem” kelimesinin sözlük anlamı "lüzumlu, gerekli”dir. Ancak bu kelime aynı zamanda hacla ilgili bir terim olup "bir şeye veya kişiye sarılmak, yapışmak" anlamındaki iltizâm masdarından türemiş ism-i mekândır ve Hacerülesved ile Kâbe kapısı arasında bulunan yerin adıdır. Kâbe’yi ziyâret edenler bu kısımda yapılacak duâların kabul edileceğine inandıkları için burada duâyla vakit geçirirler. Bu sebeple Mültezem her zaman kalabalık olur. Rahmî Efendi bir yandan yolun baştan başa düzeltilmesinin lüzumunu vurgularken öte yandan Kâbe, Mültezem, delîl (hac rehberi) gibi terimleri aynı beyit içerisinde kullanarak yapılan işin kudsiyetine atıfta bulunmuştur.

33 Kemâleddin Efendi kâfiye icâbı "bî-kāl ü kîl” olması gereken ibâreyi yaygı̀n söylenişi esas alarak "bî-kîl ü kāl" şeklinde yazmıştır. 
13. Kalmadı gel sâye-i şâhânede şîb ü firâz (1288) [1871]

Sehl olundu rehde gelsün gitsün ebnâ-yı sebîl (1288) [1871]

قالمدى كل سايهء شاهانه ده شيب و فراز

سهل اولندى رهده كلسون كيتسون ابناى سبيل

$* * * * * * * * *$

\section{Târîh-i Çeşme}

[fâ 'ilâtün fầ 'ilâtün fâ 'ilün]

1. Bü'l-himem İshak Efendi kim odur

İftihâr-1 asl-1 pâk-i hânedân

2. Yapdı eyvân itdi icrâ âb-1 nâb

Ehl-i zevke oldı bir a'lâ mekân

3. Değmesün göz deyu havz-1 çeşmeden

Sür'at-ile tîz geçer âb-1 revân

4. Zâtına ârif olanlar bak ne dir

Böyle bâğa böyle ister bâğbân

5. Hak mübârek eylesün ahbâb ile

Bağçesinde zevke baksun her zamân

6. Teşneye târîhini işrâb içün

Söyledi ilhâm-1 gaybî nâgehân

7. Bir mücevher kâse al Rahmî ele

Havza gel mâ-1 hayâtı iç hemân

حوضه كل ماء حياتى ايج همان

1283 [1866]

$* * * * * * * * *$ 


\section{Terkîb-i Bend}

[mef'ûlü mefầ îlü mefâ 'îlü fe 'ûlün]

1. Biz mülk-i kanâ'atde mekîn ehl-i gınâyız

Şâhâne tefâhur ideriz turfe gedâyız

2. Yok rağbetimiz minnet-ile atlas-1 çerhe

Bir hırka ile hem-şeref-i Âl-i Abâ'yız [57ª]

3. Îdâ‘ olunur gencimize gevher-i irfân

Hıfz eylerüz esrâr-1 Hudâ'yı ümenâyız

4. Bir bâde ile fâş ideriz râz-1 derûnu

Sahbâ-şiken-i meygede-i zühd ü riyâyız

5. Yek-reng iledir cilve-nümâ şâhid-i ihlâs

Âyîne-i rûşen-güher-i mihr ü vefâyız

6. Ağyârı fedâ gayret-i âb u kilimizdir

Yok minnetimiz gayre hemân abd-i Hudâ'yız

7. Hak'dır veren âmâli sivâ ehl-i recâdır

Kendin gibi mahlûka perestiş ne belâdır

1. Meyl itme fenâ mülküne dil verme hevâya

İlm ü amelin yoksa gider cümle hebâya

2. Âkil nice sarf eyleye sermâye-i ömrün

Pesmânde olan bir nice kâlâ-yı fenâya

3. Ukbâda olur hulle-i cennetle müzeyyen

Her kāni` olan dünyede bir köhne abâya

4. Dehrin kimedür rağbeti ya himmeti bilmem

Yok ehl-i kemâle urefâya zurefâya 
5. Fark eyleyemez küfr-ile İslâm'1 arşdan Bak zâl-1 felek itdigi şu sehv ü hatâya

6. Havf eyleme Hak hâfızıdır dîn-i mübînin Meyl eyleme mekr-i ümerâya vüzerâya

7. Kul fi' 'line her hâlde Allâh olur âgâh el-Kudretü ve'l-izzetü ve'l-hikmetü lillâh

1. Teslîmden ol sorma sakın sırr-1 kaderden Takdîr iledir her ne gelür hayr ile şerden

2. Ancak o Hudâ'dandır O'dur mâni' u mu'tî Zâhirde zuhûr eyleyen ol dest-i beşerden

3. Sen dürr-i kerîmâne-i irfânı taleb kıl Yok fâide cem‘ eylediğin sîm ile zerden

4. Bir gün de ider vâris-i dîgerleri mesrûr Her nesne ki kaldı sana mîrâs pederden

5. Mîzân-1 hakîkatde görürsün ola zâhir Sermâye-i ömründe olan sûd u zarardan [57 $\left.{ }^{\mathrm{b}}\right]$

6. Sen eyle hemân tevbe ile arz-1 münâcât Bir gice ki bîdâr olasın vakt-i seherden

7. Gafletle bu ömrün güzerân itmesün aslâ Tâ afvına mazhar ide ol Hazret-i Mevlâ

1. İzz ü şeref-i kadri bilen genc ü gınâdan Âzâd olamaz keşmekeş-i renc ü anâdan

2. Girmez eline dürr-i girânmâye-i maksûd Gavvâs gibi kesmeyen ümmîdi sivâdan

3. Bin mihnete mazhar olur ol râh-1 bekāda Her kim alamaz zâd-1 rehn mülk-i fenâdan 
4. Pûyende olur cümlesi bu râh-1 emelde Kim irdi murâda hele sor bay u gedâdan

5. Takdîr-i Hudâ ile döner hey’et-i eflâk Kevkeblerin ahkâmını sorma hukemâdan

6. Âciz kula destindeki tedbîr ne bilsün Yâr olmayıcak adama tefvîk-i Hudâ'dan

7. Hep neylediyse eyledi takdîr ezelde Teslîm olagör kalma sakın ceng ü cedelde

1. Yokdan seni var eyledi ol Hazret-i Mevlâ Her rûz ma'âşın sebebin itdi müheyyâ

2. Bildirmiş iken rızkını taksîm ezelde İtmek ne revâ sen gibi mahlûka temennâ

3. Cem' eylediklerin genc-i firâvânı ömrde Vârisler ider bir gün anı hırs-ile yağmâ

4. Bilmem kimi dâmâd idinüp kâmını virdi Böyle zer ü zîverle bezendi zen-i dünyâ

5. Bir hufre-i hâk olsa gerek meskenin âhir Sad izzet-ile olsa yerin kasr-1 mu'allâ

6. Sarf eyleme beyhûde bu sermâye-i ömrün Rahmî ele girmez hele bu gevher-i yektâ

7. Bil kadrini ibretle nazar k1l bu cihâna Terk itmedi bir ferdi murâd üzre zamâna 


\section{[58 ] Tercî́-i Bend-i Müsellem ü Merğûb: Cihâdiyye}

[mef' ûlü fầ 'ilâtü mefâ 'îlü fầ 'ilün]

1. Nakz itdi akd-1 sulhı Rusiyye nâgehân

Mağrûr-1 mülkü oldu o bedhâh u bedgümân

2. Bî-şübhe oldı mazhar-1 la'net uyandırup

Yatmıșdı fitne hâbda kalmıșdı bir zamân

3. Her bir hudûda leşker-i menhûsı sevk idüp

Zulm u fesâd u fitneyi gösterdi bu cihân

4. Her müslümâna emr-i cihâd oldı farz-1 ayn

Meydâna girdi şimdi hizberân-1 gâziyân

5. Ebrû-yı yâre gamze-i hunhâre yok nigâh

Şimdi nazrada oldı hemân seyf-ile sinân

6. Her kahramânın eldeki çevgân-1 seyfine

Gûy oldı sanki her ser-i bî-kadr-1 düşmenân

7. Eyler şikeste pençe-i pür-zûr düşmeni

Çün gâziyân-1 devr-i zamân oldı pehlevân

8. Bir pâdişâhın askeridir ki ceng ider

Kim bârgâhı gıbtageh-i cümle Hüsrevân

9. Hızr-1 huceste-nusret ceyşinde rehnümâ

Feth u zaferde seyr ü seferlerde hem-ınân

10. Sâhibkıran-1 asrdır İskender-i zamân

Şevketlü Gâzî Hazret-i Abdülhamîd Hân

1. Bir pâdişeh ki oldı dilâverler askeri

Eyler adûya harbi dilîrâne leşkeri 
2. Bir pâdişeh ki cümle-i a'dâya gösterür Hayl ü sipâhı satvet-i ceyş-i Sikender'i

3. Bir pâdişeh ki yâveri tevfîk-i Hak olur Hemrâhı çünki şer‘-i şerîf-i peyemberî

4. Bir pâdişeh ki milket-i İslâm'a bî-nizâ‘ Şâhân ü Hüsrevânın odur şimdi serveri

5. Bir pâdişeh ki leşkeri şîrâne cümlede Gösterdi ceyş-i düşmenine ceng-i Hayder'i

6. Bir pâdişeh ki dest-i kerem-pâşı dem-be-dem Mânend-i bahr ü kân saçar dürr ü gevheri [58 $\left.{ }^{\mathrm{b}}\right]$

7. Bir pâdişeh ki zât-1 sürûşı sıfâtına Mahsûs adl ü cûd u sehâ mülk-perveri' ${ }^{34}$

8. Bir pâdişeh ki şa 'şa'a-i nûr-1 adl ile Açdı zalâm-1 muzlime-i semt-i hâveri

9. Bir pâdişeh ki leşker-i encüm-şümâr ile Tutdı sadâ-yı saltanatı heft kişveri

10. Sâhibkıran-ı asrdır İskender-i zamân
Şevketlü Gâzî Hazret-i Abdülhamîd Hân

1. Tedbîr ü rây-1 pür hükm-i sadr-1 a'zamî Andırdı hüsn-i terbiyet-i İbn Edhem'i

2. Her ordugâha oldu kumandan bir müşîr Her bir müşîr mes’ele-i harbin a'lemi

3. Osman Gâzî Hazret-i Paşa ale'l-husûs

Harb-1 adûda âlemin oldı müsellemi 
4. İşte Plevne cengine parlatdı seyfini

Bir yara açdı düşmene yok şimdi merhemi

5. Şıpka gazâsın itdi Süleymân müşîr-i şîr

Kurdı cibâl-i şâhikaya seyf-i süllemi

6. Gâzî müşîr Ahmed Muhtâr-1 nâmdâr

A'dâ-yı dîne tîğ-1 kazâ oldı mübremi

7. Dervîş-i şîr-pîşe-i gavgâ müşîr-i has

Tîğ u teberle oldı guzâtun mükerremi

8. Bir hamle ile vâlî-i vâlâ-yı Erzurum

Çeşm-i adûya cengde teng itdi âlemi

9. Hırz-1 yemîn-i devlet-i şâh-1 cihândır

Bî-șübhe mülk ü saltanatın harb-1 a'zamı ${ }^{35}$

10. Sâhibkıran-1 asrdır İskender-i zamân

Şevketlü Gâzî Hazret-i Abdülhamîd Hân

1. Gâzî-nihâd leşkeri çün azm-i hûn ider

Sahrâyı hûn-1 düşmenle lâle-gûn ider

2. Arz eyledikçe hışmla şimşîr-i sehm-nâk

Bir hamlesinde hasmını zâr u zebûn ider

3. Bâzâr-1 bergüzâr-1 vegâ buldı iştihâr

Nakd-1 hayât sarfinı a'dâ füzûn ider [59ª]

4. Hâkister oldı âteş-i hırmân-1la adû

Baht-1 siyâhı hâbgehin böyle tün ider

5. Gördükçe böyle râyet-i İslâm'ı ser-firâz

Elde livâ-yı nahsi adû ser-nigûn ider

35 İkinci mısrâdaki "mülk" kelimesi iki defa yazılmıştır. 
6. Mânend-i lâle garka-i hûnâb-1 kahr olur Kûh-1 siyâhı mülküne dâğ-1 derûn ider

7. Efsâne oldı leşkeri bu inhizâmla

Sad-reng gerçi arz iderek bin füsûn ider

8. Ferzâne sürdi düşmen-i dîn bilmeyene hak

Böyle semend-i bahtını tünd ü harûn ider

9. Bir pâdişeh ki böyle Sikender-sipâh olur

Her bir seferde Hızr'1 Hudâ reh-nümûn ider

10. Sâhibkıran-1 asrdır İskender-i zamân
Şevketlü Gâzî Hazret-i Abdülhamîd Hân

1. Bir pâdişeh ki leşkeri hep gâziyân olur Hâli hemîşe düşmen-i dînin yaman olur

2. Şîrâne hamle etmede şimşîr-i kahr ile Ceng-i adûda her biri bir kahramân olur

3. Cânbâz-1 çarh şa 'bede gösterdi ortada Bâzîçesinde cünbüş-i seyf ü sinân olur

4. Eyler azâb-1 dûzahı tenbîh kâfire ${ }^{36}$ Top u tüfengi nerde ki âteş-feşân olur

5. Tûfân kopdu başına asker değil meger Seylâbdır ki mülk-i adüvve revân olur

6. İtmiş azâb kâfire çün kıbtiyân-var Nehr-i sirişk-i çeşm-i adû şimdi kan olur

7. Sahrâ-yı rezmgâhı bütün lâlezâr ider Gâzîlerin ki nîzeleri hûn-feşân olur

36 Misrâdaki son kelime "düşmene" şeklindedir. Fakat bu ifade derkenâr notunda "kâfire" kelimesiyle tashih edilmiştir. 
8. Kim gördü böyle leşker-i hûnrîz-i saf-şiken

Her demde tîğ-i tîzleri cân-sitân olur

9. Avn-i Hak ile gâlib olur cünd-i pâdişâh

Bu şevket-ile mefhar-i Osmâniyân olur

10. Sâhibkıran-1 asrdır İskender-i zamân

Şevketlü Gâzî Hazret-i Abdülhamîd Hân [59'b]

1. Düşmen-i gurûra bendle ceng ü vegâsını

Gösterdi kibr ü nahvetle harb edâsını

2. Her demde oldı leşkeri makhûr u münhezim

Her yerde gitdi kahkarî buldı belâsını

3. Bir derde oldı şimdi ki Rusiyye mübtelâ

Bilmez hakîm-i asr da aslâ devâsını

4. Göstermiş idi mu'cize 1zhâr-1 dîn içün

Fir'avniyâna Hazret-i Mûsâ asâsını

5. İslâm'ın işte topu da âteş-feşân olur

Arz itdi sanki dîn-i mübîn ejdehâsını

6. İslâm'a küfrü tutdu mukābil ki ceng ider

Bir zulmet içre kaldı ki bilmez hatâsını

7. Eyler hezâr şermle teslîm mülkini

Bin tevbe ile kurtarabilse yakasını

8. Görmez misâl-i şebpere dîn âfitâbını

İtmiş serinde hayr dalâlet belâsını

9. A'dâ-y1 dînin işte yeri âteş olduğun

Dünyâya böyle gösterir Allah cezâsını

10. Sâhibkıran-1 asrdır İskender-i zamân

Şevketlü Gâzî Hazret-i Abdülhamîd Hân 
1. Adl-azmâ-yı halk-1 cihân özge şâhdır Kişver-güşâ-yı devr-i zamân-ı pâdişâhdır

2. Hep sâyesinde emn ü emân olsa var yeri Bî-şübhe fark-1 âleme zıll-1 İlâh'dır

3. Azm itdi rezme leşker-i encüm-şümârı gör Hakkā ki pâdişâh-1 Sikender-i sipâhdır

4. Ceng-i adûda şöyle tarabnâk-1 askerî San kim zemîn-i ma'reke bir 'îdgâhdır

5. Her yerde düşmen olmada makhûr u münhezim Nusret-i Hudâ'dan olduğu bî-iştibâhdır

6. İtmiş livâ-yı feth u zafer adl ile kıyâm İsbâta inhizâmını hasmın güvâhdır

7. Gâzîler işte izzet u nusretle rû-sefî̀ Düşmen-i sevâd-1 zillet rû-siyâhdır

8. Hisn-1 hasîn-i mülkini itdiler penâh Çerkes Abaza halkı bütün dâd-hâhdır [60ª

9. Vâcibdür işte herkese emrine imtisâl Çünkim gazâyı terk büyük bir günâhdır

10. Sâhibkıran-1 asrdır İskender-i zamân Şevketlü Gâzî Hazret-i Abdülhamîd Hân

1. Evreng-i şâhî zâtı ile itsün iftihâr

Çok asra irdi görmedi böyle şehryâr

2. Zeyn eyledikçe taht-1 hümâyûnı yümn ile Evvel cihâda rağbetini itdi ihtiyâr

3. Fârûkî seyfi bend-i miyân itdi harb içün Arz itdi rû-yı düşmene şîrâne Zü'l-fikār 
4. Her bir gazâda sanki gazanferler askeri Bir ferdi rûz-1 ma'reke bir merd-i pâydâr

5. Nâm aldı kâr-zârda her yerde leşkeri

Şân aldı gâlibiyyet ile buldı iştihâr

6. Şîrâne hamle eyleyerek kalb-i düşmene

Her ordusunda oldu kumandanı bahtiyâr

7. İtdi cünûd-1 saf-şiken tîr-efgeni

Hep tâğiyân-1 Sirb ü Karatağ'1 târ-mâr

8. Yâ Rab bi-câhi kevkebe-i Fahr-i Kâinât

Yâ Rab bi-hakk-1 seyf-i cihâd-1 çehâr yâr

9. Sen pâdişâh-1 âlemi her dem muzaffer it Her bir gazâda nusret ile ola nâmdâr

10. Sâhibkıran-1 asrdır İskender-i zamân

Şevketlü Gâzî Hazret-i Abdülhamîd Hân

1. Her müslümâna lâzım olan böyledir cihâd

Eyler gazâya pâdişeh emriyle ictihâd

2. Çâbüksüvâr-1 arsa-i pehnâ-yı rezm olup Harb-i adûda avn-1 Hakk'a eyler i'timâd

3. Gâhi şehâdet almağa eyler fedâ-yı cân

Gâhi adûyı katle ider himmetin ziyâd

4. Yâ Rab bi-hakk-1 âyet-i seyf-i adû-şiken

Sen gâziyânı feth-i mübîn-ile eyle şâd

5. Her dem sürûra mazhar ordugâhlar

Fevz ü zaferle leşker-i şâh ola ber-murâd $\left[60^{\mathrm{b}}\right]$

6. Her yerde eyle düşmeni makhûr u münhezim

Hergiz mukābil olmaya a'dâ-yı bed-nihâd 
7. Kalsun miyân-1 tefrikada düşmen askeri

Bulsun hemîşe leşker-i İslâm ittihâd

8. Bir şeb senâ-yı saltanat evrâd-ı hâs iken

Tenbîh böyle eyledi ilhâm-1 bâmdâd

9. Rahmî bu beyt-i dilkeş-i âlem-pesend ile

Sen pâdişâh-1 âlemi her demde eyle yâd

10. Sâhibkıran-1 asrdır İskender-i zamân

Şevketlü Gâzî Hazret-i Abdülhamîd Hân

$* * * * * * * * *$

b) Rahmî Efendi’nin Harputlu Hâfız Yusuf Efendi'nin Vefâtı Sebebiyle Onun Talebesi Abdülhamid Hamdî Efendi’ye Gönderdiği Taziyenâme ve Hamdî Efendi'nin Cevâbı

[62ª] 1299 [1882] senesi Rebîülevvel'de Harput'da Reîsü'l-kurrâ fazîletlü Hacı Hâfız Yusuf Efendi Hazretleri intikāl-1 dâr-1 bekā buyurdukları zamânda Rahmî Efendi fazîletlü Hacı Abdülhamîd Hamdî Efendi Hazretlerine tahrîr eylediği ta'ziyenâmedir:

Fazîletlü efendim hazretleri,

Ebkākumullâhu Te`âlâ bi'l-ömri’s-sermediyyi ma‘a'l-evlâdi ve'l-âbâ. ${ }^{37}$ Hayfâ vâ esefâ! Kıdvet-i ehl-i vefâ hatîb-i minber-i sıdk u safâ fahru'l-ulemâ ve'l-urefâ ve'z-zurefâ hâce-i kırâathâne-i kelâm-1 Hudâ reîsü'l-kurrâ efendinin terk-i medrese-i fenâ iderek âzim-i dershâne-i bekā oldukları umûm ehl-i beldeye şümûl gumûmı musîbet-i uzmâ olduğu misillü bilhâssa zât-1 ulyâ-yı hakāyık-dânîlerine mevrûs ekdâr ü ahzân-1 lâ-yuhsâ olacağından mahsûsen tesliyete sezâ ve ahrâ olacaklarını kalb-i hazîn-i âcizîye ilhâm-1 Samedânî îfâ ve inbâ eylemeğin Rabbimiz Te‘âlâ ve Tekaddes Hazretleri zât-1 mekârim-simât-1 muhârese âyât-1 fâzılânelerini meda'dduhûr zîb-i mesânid-i dershâne-i hayât birle nâil-i mînâ-yı dekāyık-1 hakāyık-1 ulûm u âyât eylemesi du'âlarında olduğum beyânı rakîme-i âcizî terakkum-ter(?) olmuşdur. Bi-mennihi Te'âlâ ba'de ... ${ }^{38}$ dahi savb-1 âcizânemi adem-i tesliyet-me'lûfı olduğum hüsn-i teveccühât-1 semûhîleri îfâsı bâbında irâde efendimindir. 15 Rebîülevvel 299 [4 Şubat 1882]

37 Bu cümle "Allah sizleri baba ve çocuklarınızla birlikte ebedî bir ömürle muammer eylesin.” mânâsına gelmektedir. Rahmî Efendi bu taziyenâmeyi yazdığında Abdülhamid Hamdî Efendi’nin babası Ömer Naîmî Efendi henüz sağdır. Fakat yaklaşık üç ay sonra (11 Cemâziyelâhir 1299/30 Nisan 1882) o da vefât edecektir.

38 Buradaki kelimesini okuyamadık. 


\section{Cevâbı}

Fazîletlü efendim hazretleri,

Bu def'a üstâd-ı fezâil-mu'tâdımız merhûm ve mağfûr hacı kurrâ efendinin

azm-dâr-1 bekā ve seyr-i serâbistân-1 cennât-1

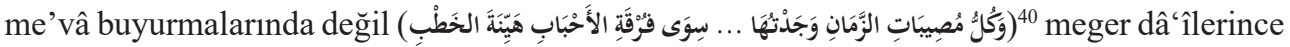
vukû'a gelen teessür-i fevkal'âde hâtır-1 ... ${ }^{41}$

\section{c) AÜİF Kütüphanesi'ndeki Bir Yazma Mecmuada Mevcut Şiirleri ${ }^{42}$}

\section{Târîh-i Rahmî Efendi Hoğuvî}

[fâ'ilâtün fâ'ilâtün (fe'ilâtün) fâ‘ilâtün fâ‘ilün]

1. Şükr Mevlâ'ya bu şeb lutf-1 Hudâ itdi zuhûr

Matla'-1 burc-1 sa'âdetde zuhûr eyledi nûr

2. Hamd ola Hamdî Efendi’ye virüp Hazret-i Hak

Ya'nî bir hayr-1 halef tıfl-1 zekiyy-i Mansûr

3. Kurretü'l-ayn-i eb ü ceddi olup gevher-i pâk

Dîdeler rûşen olup oldu gönüller mesrûr

39 "Heyhât! Zaman onun gibisini bir daha getirmez! Gerçekten zaman bu hususta çok cimridir!" anlamına gelen bu beyit Abbasi döneminin meşhur Arap şâirlerinden Ebû Temmâm et-Tâî’ye (ö. 231/846) âittir. bk. Dîvânu Ebî Temmâm et-Tâî (haz. Muhyiddîn el-Hayyât), yy., Nezâretü'l-Ma'ârifi'l-Umûmiyye, 1973, s. 375. (Beyit Ebû Temmâm'ın Muhammed b. Hamîd için yazdığı mersiyesinde yer almaktadır.)

40 "Zamanın bütün musibetlerinin üstesinden kolaylıkla gelebildim. Ama dosttan ayrılmanın acısıyla baş edemedim." anlamındaki bu beyit Hz. Hüseyin'in süt kardeşi Kays b. Zerîh'e (68/687) âittir. (Şâirin babasının ismi bazı kaynaklarda Züreyh olarak da geçmektedir.) bk. Dîvânu Kays b. Züreyh (nşr. ve şrh. Abdurrahman el-Mustâvî), Beyrut: Dârü'l-Ma'rife, 2004, s. 59.

41 Metin burada bitmektedir.

42 AÜİF Kütüphanesi'ne bağışlanan Efendigil Koleksiyonu'nda bulunan bu mecmua 0036 demirbaş numarasıyla kayıtlıdır. Mecmua Abdülhamid Hamdî Efendi ve Kemâleddin Efendi’nin el yazılarıyla yazılmış olup dinî ilimlere dâir birtakım notlar ihtivâ etmektedir. 
4. Cedd-i a'lâsını hem-nâmı olup şâd itdi' ${ }^{43}$

Vâris-i ‘ilm ü kemâli ide ol Rabb-1 Gayûr

5. Çâr-yârin mededi ile denildi târîh

'Ömr-i sermedle emîn ola Muhammed Mansûr

عمر سرمدله امين اوله محمد منصور

$[1270+4=1274 / 1857]^{44}$

$* * * * * * * * *$

\section{Güfte-i Rahmî Der Vefât-ı Ceddîn ${ }^{45}$}

[mefầ ‘̂̀ün mefâ 'îlün fe 'îlün]

1. Semiyy-i hazret-i Fârûk-1 a'zam

Kerîm ü hânedân idi kadîmî

2. İderdi neşr-i ilme sarf ömrün

Kemâl ü fazl idi gûyâ nedîmi

3. Kasîde şârihi meşhûr-1 âfâk ${ }^{46}$

Müfessir idi Kur'ân-1 Kerîm'i

4. Gidüp terk eyledi dâr-1 fenâyı

Huzûra arz ider kalb-i selîmi

43 [Mecmuadaki not:] Murâd Mehmed Sa‘îd Efendi’dir. Mehmed Saîd Efendi, Abdülhamid Hamdî Efendi’nin dedesi Hacı Ahmed Efendi’nin babasıdır. Sunguroğlu’na göre Said Efendi Harput’ta kırk yıl müftülük yapmış, XIX. asrın başlarında vefât etmiştir. Sunguroğlu onun vefât tarihini milâdî 1804, hicrî 1210 olarak vermektedir. Ancak bu tarihler birbirini tutmamaktadır. Zira 1804'ün hicrî karşılığ1 1217-1218; 1210'un milâdî karş1lığ1 1795-1796'dır. Dolayısıyle onun herhangi bir kaynak belirtmeksizin yazdığı Said Efendi'nin 1137/1725'te doğup seksen iki yıl yaşadığı şeklindeki bilgisine de ihtiyatla yaklaşmak gerekir. (bk. İshak Sunguroğlu, Harput Yollarında, II, 147.)

44 Mecmûa, AÜİF Kütüphanesi, Yazmalar Blm., nr. 36, s. 147 (Hamdî Efendi bu şiiri 36143 demirbaş numarasıyla kayıtlı mecmuasına da kaydetmiştir [vr. nr. yok]. Bu şiiri daha önce Kemâleddin Efendi'nin şiirlerini konu edindiğimiz makalede yayımlamıştık. Mehmed Said Efendi'nin hayatı ve buna dair kaynaklar için bk. Ahmet Karataş, "Kemâleddin Harputî Efendi’nin Şiirleri”, Marmara Üniversitesi İlâhiyat Fakültesi Dergisi, sy. 50 [2016], s. 97-98.)

45 Manzûmenin başına bu kaydı Kemâleddin Efendi ilâve etmiştir.

46 Ömer Naîmî Efendi, Bûsîrî’nin (ö. 695/1296) Hz. Peygamber'i medheden meşhur kasidesi Kasîdetü'l-bürde'yi Asîdetü'ş-şühde şerhi Kasideti'l-Bürde adıyla Arapça şerhetmiş, bu şerh birçok defa basılmış ve ona İslâm dünyasında şöhret kazandırmıştır. 
5. İdenler türbe-i pâkin ziyâret

Du'â-yı hayr ider elbet samîmî

6. Oku bir Fâtiha eyle du'ây1

Niyâz it rahmet-i Rabb-1 Rahîm'i

7. Dirîgâ gitdi "bir” fâzıl bu târîh

Makāmın itdi cennâtı Na‘îmî

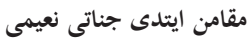

$[1300-1=1299]^{47}$

\section{Güfte-i Rahmî Der Mürd-Şoden-i Na'um-ı Zimmî}

Kārûn'dan özge kimse berâber götürmedi

Kâfir de işte kurtulamaz baht-1 şûmdan

Zîr-i zemîne gitdi gider mâl ü mülki kor

Mağrûr olan da ibreti alsun $\mathrm{Na}^{6} \mathrm{um}^{\prime} \mathrm{dan}^{48}$

d) Mamûtetülazîz Gazetesinde Yayımlanan Tarih Manzûmeleri

[fâ 'ilâtün fầ 'ilâtün fâ 'ilâtün fâ 'ilün]

1. Vâlî-i âlî-himem ol kâmrân-1 muhterem

Dâver-i ekrem Hasan Beg zâir-i Beyt-i Hudâ

2. Râh-1 takvâda tarîk-i müstakîmi seyr içün Hâdî-i tevfîk-i Hak olmuş o zâta rehnümâ

3. Nakd-i vakt-i ömrünü hayrâta ya'nî sarf idüp

Hasbeten lillâh yolunda çeşmeler itdi binâ

4. İşte ezcümle bu vâlâ çeşme-i müstahkemi

Eylemiş tevsîm gûyâ ki sitem-sâr-1 kazâ

47 Mecmûa, AÜİF Kütüphanesi, Yazmalar Blm., nr. 36, s. 142.

48 Mecmûa, AÜİF Kütüphanesi, Yazmalar Blm., nr. 36, s. 143. Naum hakkında bilgi bulamadık. Ancak kıt'adan Rahmî Efendi'nin tanıdığı zengin bir Ermeni olduğu anlaşılmaktadır. 
5. Efdal-i a'mâldir icrâ-yı âb-1 hoş-güvâr

Havz-1 Kevser'le mübeşşer ola ol yevme'l-cezâ

6. Her gören elbet cevâhir-pâş olup tahsîn ider

Rahmiyâ bu beyt-i ra"nâ itdi târîhin edâ

7. Böyle inşâ eyledi Hâcı Hasan Beg çeşmeyi

Gel de nûş eyle hemân bânîsine eyle du'â

كل ده نوش ايله همان بانيسنه ايله دعا

$1302[1885]^{49}$

$* * * * * * * * *$

[mefầ îlün mefâ î̀lün mefấ îlün mefâ 'îlün]

1. Cenâb-1 dâver Hâcı Hasan Beg vâli-i ekrem

Hemâre kevkeb-i ikbâli bir cünde sebât olsun

2. Nukûd-ı himmet-i ulyâsı hayrâta olur masrûf

Kabûl-1 dergeh-i vâlâ-yı Rabb-1 kâinât olsun

3. Yolunda işte bu bir çeşmeyi de eyledi inşâ

Kemer gibi sevâbı defterinde iki kat olsun

4. Du'â-yı hayr ile yâd eylesünler teşnegân-1 râh

Cezâsı rûz-1 mahşer Kevser ü mâ-i Fırât olsun

5. İki destimle Rahmî nûş idince söyledim târîh Hasan Beg çeşmesinden gel de iç âb-1 hayât olsun

حسن بك حشمه سندن كل ده ايج اب حيات اولسون

$1302[1885]^{50}$

$* * * * * * * * *$

49 Ma'mûretülazîz Gazetesi, nr. 88, 15 Ramazan 1302/29 Haziran 1885, s. 1.

50 Ma'mûretülazîz Gazetesi, nr. 92, 20 Şevvâl 1302/2 Ağustos 1885, s. 2-3. 
[mefâ 'îlün mefầ îlün mefâ 'îlün mefâ 'îlün]

1. Cenâb-1 zâir-i beytü'l-Harem ol vâli-i ekrem Hasan Beg âb-1 lutfı oldu cârî zîr ü bâlâya

2. Mahallinde nukûd-1 himmete sarf eyleyüp bö[yle]

Muvaffak oldı avn-1 Hak'la bu hayrâtı in[şâya]

3. Karasaz vâdi-i tengini zulmâta idüp teşbîh ${ }^{51}$

Görüp ayne'l-hayâtı sanasın sa'y itdi icrâ[ya]

4. Zülâl-âsâne âb-1 hoşgüvâr-1 hayret efz[âsın]

Safâsı gıbta-fermâ oldu mir'ât-1 m[ücellâya]

5. Cezâsı selsebîl-i cennet olsun her görenler dir Muvâfik geldi zîrâ meşreb-i a'lâ vü dânâya

6. Getürsün yâda Rahmî gevher-i eşk-ile yaz [târî]h

Nigâh itdikçe her bir teşneler bu beyt-i r[a'nâya]

7. Hüseyn'in aşkına vâlî Hasan Beg çeşme yapdırdı

Gel iç su eyle bânîye du'â hem şükr Mevlâ’ya

كل ايج صو ايله باني يه دعا هم شكر مولايه

$1302[1885]^{52}$

\section{Sonuç}

XIX. asır Harput'unun önde gelen şâirlerinden olan Rahmî Efendi merkeze yaklaşık 20 km. uzaklıktaki ova köylerinden Hoğu'da (Yurtbaşı) doğmuş, Harput, Antep ve Kayseri'de aldığı medrese tahsilini müteâkip tekrar köyüne gelerek burada vefâtına kadar ilim ve şiirle meşgul olmuştur. Şiirlerinde büyük ölçüde Fuzûlî ve Nâbî’nin tesiri altında kalmış, bununla birlikte adını ibkâ edecek evsâfta gazeller yazmaya muvaffak olmuştur. Yazdığı tarih manzûmeleri ve nazireler şöhretini artırmış, latife severliği, hoş sohbeti sayesinde dost meclislerinin aranan siması hâline gelmiştir.

Harput müftülerinden Müftügil/Efendigil nâmıyla tanınan Hacı Ömer Naîmî Efendi Rahmî Efendi’nin yakın arkadaşıdır. Her ikisi Harput’taki ilk medrese tahsillerini Ömer Naîmî Efendi'nin

51 Karasaz Elazığg'a 22 km. mesâfede bir köydür. Bu civardaki Deveboynu geçidi Ma‘mûretülazîz Diyarbekir yolunun zor güzergâhlarından biriydi.

52 Bir çok mısrâın son kelimeleri dizgi yahut çekim hatası sebebiyle çıkmadığından eksikleri vezne ve kâfiyeye uygun olarak tamamladık. Şiir için bk. Ma 'mûretülazîz Gazetesi, nr. 96, 19 Zilka'de 1302/30 Ağustos 1885, s. 2. 
babası müftü Hacı Ahmed Efendi'den (ö. 1261/1845) almışlardır. Rahmî Efendi, Ömer Naîmî Efendi’nin oğlu müderris Hacı Abdülhamdi Hamdî Efendi’nin de ahbâbıdır. Ma‘mûretülazîz müftülerinden müderris Kemâleddin Efendi ise Abdülhamid Hamdî Efendi'nin oğludur. Kemâleddin Efendi Ramazan 1298/Ağustos 1881'de henüz 14 yaşındayken Rahmî Efendi'nin divânını istinsâh etmiştir. Ankara Üniversitesi İlâhiyat Fakültesi Kütüphanesi'ndeki Efendigil Kitap Koleksiyonu'nun yazmaları arasında bulunan bu nüshayı tespit edip eski ve yeni harfli matbu divânlarla karşılaştırdığımızda onun mevzubahis neşirlerde olmayan birtakım şiirlerini gördük. Bunlardan Harput Sare Hatun Camii'nin yeniden inşâsı münâsebetiyle 1259/1843'te yazdığg tarih manzûmesini yakın zamanda yayımladığımız için geriye kalanları bu makale vasıtasıyla gün yüzüne çıkarmaya çalıştık. Yine Rahmî Efendi’nin aynı koleksiyondaki bir başka mecmua ile Ma 'mûretü' l-azîz Gazetesinde bulduğumuz birkaç şiirini de makalemize ilâve ettik. ${ }^{53}$ Bu makaledeki manzûmeler Harput kültür tarihi başta olmak üzere Osmanl1-Sırp ve Osmanl1-Rus savaşlarına dair bilgiler içermesi, Rahmî Efendi'nin memleketi ilgilendiren meselelere ve devlet adamlarının başarılı icraatlarına kayıtsız kalmadığını göstermesi bakımından ehemmiyet arz etmektedir.

\footnotetext{
Hakem Değerlendirmesi: Dış bağımsız.

Çıkar Çatışması: Yazar çıkar çatışması bildirmemiş̧ir.

Finansal Destek: Yazar bu çalışma için finansal destek almadığını beyan etmiştir.

Peer-review: Externally peer-reviewed.

Conflict of Interest: The author has no conflict of interest to declare.

Grant Support: The author declared that this study has received no financial support.
}

\section{Kaynakça/References}

Arslan, Mehmet, "Hasan Hakkı Paşa, İşkodralı”, http://www. turkedebiyatiisimler sozlugu.com [erişim tarihi: 20.02.2020].

Aydın, Mahir, “Doksanüç Harbi”, DİA, IX, İstanbul 1994, 498-499.

Beysanoğlu, Şevket, Diyarbakırlı Fikir ve Sanat Adamları, I-II, İstanbul: Iş11 Matbaası, 1957-1960.

Cengiz, Halil Erdoğan- Eren, Gönül Hatay, Rahmi-i Harputî Divanı, Ankara: Kültür Bakanlığı Yayınları, 1996. Dîvân-ı Rahmî̀-i Harputî, Ma‘mûretü'l-azîz: Vilâyet Matbaası, 1303.

Dîvânu Ebî Temmâm et-Tâ̂̀ (haz. Muhyiddîn el-Hayyât), yy., Nezâretü’l-Ma‘ârifi'l-Umûmiyye, 1973.

Dîvânu Kays b. Züreyh (nşr. ve şrh. Abdurrahman el-Mustâvî), Beyrut: Dârü’l-Ma'rife, 2004.

Eser-i Merhûm Ziyâ Paşa: Tercî-i Bend ve Terkîb-i Bend, İstanbul: Ahmed Kâmil ve Şerîki Matbaası, 1928. Gencer, Ali İhsan, “Ayastefanos Antlaşması”, DİA, İstanbul 1991, IV.

İnal, İbnülemin Mahmud Kemal, Son Asır Türk Şairleri, I-IV, İstanbul: Milli Eğitim Basımevi, 1969-1970.

53 Makalemizi tamamladıktan sonra Rahmî Efendi'nin Elazı̆̆'ın eski merkez köylerinden Hüseynik’te (şimdiki Ulukent mahallesi) bulunan camiin ve minâresinin inşâsına tarih düşürdüğünden, bu manzumelerin ikişer beytinin iki ayrı kıt'a hâlinde oraya hakkedildiğinden Mehmet Barutçu Bey vasıtasıyla haberdâr olduk. Tarih beyitlerinden anlaşıldığına göre camiin inşâsı 1283/1866'da, minârenin ise 1284/1867'de tamamlanmıştır. Makalemiz hakem ve dizgi sürecini geçip baskı aşamasına geldiği için söz konusu kıt'aları buraya kaydetme imkânı bulamadık. 
Karal, Enver Ziya, Osmanlı Tarihi: Birinci Meşrutiyet ve Istibdat Devirleri (1876-1907), VIII, Ankara: Türk Tarih Kurumu, 2007.

Karaman, Oktay, 'Diyarbakır Valisi Hatunoğlu Kurt İsmail Hakkı Paşa'nın Diyarbakır'daki Aşiretleri Islah ve İskân Çalışması [1868-1875]', History Studies International Journal of History: Uluslararası Tarih Araştırmaları Dergisi [Prof. Dr. Enver Konukçu Armağanı], Samsun 2012, s. 227-249.

Karataş, Ahmet, "Harput Ulemâsından Müderris-Müftü Mehmed Kemâleddin Efendi”, Marmara Üniversitesi Ilâhiyat Fakültesi Dergisi, sy. 49 (2015), s. 29-126.

Karataş, Ahmet, “Kemâleddin Harputî Efendi’nin Şiirleri”, Marmara Üniversitesi İlâhiyat Fakültesi Dergisi, sy. 50 (2016), s. 71-135.

Karataş, Ahmet, "Yeni Bilgiler Işı̆̆ında Harputlu Şâir Rahmî Efendi ve Sâre Hatun (Sarahatun) Camii’nin Yeniden İnşâsına Yazdığı Kaside”, Fırat Üniversitesi Harput Araştırmaları Dergisi, VII/13 (2020), s. 51-86.

Kavaz, İbrahim - Onur, M. Naci, Harputlu Rahmî Dîvânı, Ankara: İzzet Paşa Vakfı Yayınları (Ertem Matbaası), 1996.

Ma'mûretülazîz Gazetesi, nr. 88, 15 Ramazan 1302/29 Haziran 1885, s. 1.

Ma'mûretülazîz Gazetesi, nr. 92, 20 Şevvâl 1302/2 Ağustos 1885, s. 2-3.

Ma 'mûretülazîz Gazetesi, nr. 96, 19 Zilka'de 1302/30 Ağustos 1885, s. 2.

Mecmûa, AÜİF Kütüphanesi, Yazmalar Blm., nr. 36.

Mecmûa, AÜIFF Kütüphanesi, Yazmalar Blm., nr. 36143.

Rahmî-i Harputî, Dîvân, AÜİF Kütüphanesi, Yazmalar Blm., nr. 36812.

Sunguroğlu, İshak, Harput Yollarında, I-IV, İstanbul: Elazığ Kültür ve Tanıtma Vakfı Yayınları, 1958-1968.

Yalçın, Hayriye, Sırp Çete Hareketleri ve Osmanlı Devleti (1804-1878), yüksek lisans tezi, 2010, Gazi Üniversitesi Sosyal Bilimler Enstitüsü. 